\title{
Physical and biological factors affect the vertical distribution of larvae of benthic gastropods in a shallow embayment
}

\author{
Michelle J. Lloyd ${ }^{1, *}$, Anna Metaxas ${ }^{1}$, Brad deYoung ${ }^{2}$ \\ ${ }^{1}$ Department of Oceanography, Dalhousie University, Halifax, Nova Scotia, Canada B3H 4R2 \\ ${ }^{2}$ Department of Physics and Physical Oceanography, Memorial University, St. John's, Newfoundland, Canada A1B 3X7
}

\begin{abstract}
Marine gastropods form a diverse taxonomic group, yet little is known about the factors that affect their larval distribution and abundance. We investigated the larval vertical distribution and abundance of 9 meroplanktonic gastropod taxa (Margarites spp., Crepidula spp., Astyris lunata, Diaphana minuta, Littorinimorpha, Arrhoges occidentalis, Ilyanassa spp., Bittiolum alternatum and Nudibranchia), with similar morphology and swimming abilities, but different adult habitats and life-history strategies. We explored the role of physical (temperature, salinity, density, current velocities) and biological (fluorescence) factors, as well as periodic cycles (lunar phase, tidal state, diel period) in regulating larval vertical distribution. Using a pump, we collected plankton samples at 6 depths $(3,6,9,12,18$ and $24 \mathrm{~m})$ at each tidal state, every $2 \mathrm{~h}$ over a 36 and a $26 \mathrm{~h}$ period, during a spring and neap tide, respectively, in St. George's Bay, Nova Scotia. Concurrently, we measured temperature, salinity, density, fluorescence (as a proxy for chlorophyll, i.e. phytoplankton density), and current velocity. Larval abundance was most strongly related to temperature, except for Littorinimorpha and Crepidula spp., for which it was most strongly related to fluorescence. Margarites spp., A. lunata, Ilyanassa spp. and B. alternatum exhibited either diel or reverse-diel vertical migration during 1 or both lunar phases. For Crepidula spp., Littorinimorpha, A. occidentalis and Nudibranchia, larval vertical distribution differed between lunar phases. Only the larval vertical distribution of Margarites spp., D. minuta and Ilyanassa spp. varied with tidal state during 1 or both lunar phases. The key factors determining the vertical distribution of gastropod larvae were temperature, fluorescence, and light, although the importance of each factor varied among taxa. Differences in vertical distribution may enable these larvae to partition over a wide range of potential habitats for settlement.
\end{abstract}

KEY WORDS: Vertical migration $\cdot$ Temperature $\cdot$ Fluorescence $\cdot$ Lunar phase $\cdot$ Diel period $\cdot$ Tidal state $\cdot$ Water column structure $\cdot$ Stratification

\section{INTRODUCTION}

Dispersal strongly influences the distribution, abundance and survival of marine benthic invertebrates (Roughgarden et al. 1994), and can in turn be strongly influenced by the vertical position of larvae in the water column. For example, larvae found deeper in the water column are more likely to be retained near source populations, because of weaker currents at depth. Thus, contrasting requirements of different larval taxa may result in variation in their distributional range in the water column to maximize survival, growth and settlement rates. However, little is known about the patterns in larval distribution and abundance of gastropods while in the plankton. Gastropod larvae demonstrate a range of planktonic larval durations (days to months), and developmental (direct, lecithotrophic, planktotrophic) and feeding (feeding, non-feeding, facultative) modes (Strathmann 1987 a, Shanks 2001), and likely exhibit a vari- 
ety of behaviours (Young 1995). Such taxon-specific characteristics enable gastropods to utilize a variety of strategies while in the plankton.

Many meroplanktonic larvae can alter their vertical position, through changes in buoyancy or by ciliary or muscular activity, in response to abiotic (temperature, salinity, pressure, gravity, currents, light, turbulence) or biotic (predators, food, conspecifics) cues (Young 1995). Sensory detection of these cues can affect larval direction of movement and swimming behaviour (acceleration, deceleration, cessation). For example, larvae of the Caribbean gastropod Strombus gigas swim towards horizontal and vertical light fields, although their responsiveness to light decreases with age (Barile et al. 1994). Gastropod larvae can perceive odour, light, temperature, salinity, pressure and gravity (Kingsford et al. 2002), however, their behavioural responses to these cues are mostly unknown.

Physical (thermoclines, haloclines, pycnoclines) or biological (food patches) discontinuities in the water column can affect larval vertical distribution (Tremblay \& Sinclair 1990, Raby et al. 1994, Metaxas \& Young 1998, Sameoto \& Metaxas 2008, Daigle \& Metaxas 2011). Physical clines often restrict bivalve larvae to a particular layer (Tremblay \& Sinclair 1990, Gallager et al. 1996) due to changes in buoyancy. Alternatively, larvae may actively alter their position in response to stratification (Gallager et al. 1996, Metaxas 2001, Sameoto \& Metaxas 2008, Daigle \& Metaxas 2011). Bivalve and echinoderm larvae also aggregate around chlorophyll, i.e. food maxima (Raby et al. 1994, Metaxas \& Young 1998), unless prevented by a physical discontinuity (Gallager et al. 1996, Metaxas \& Young 1998, Sameoto \& Metaxas 2008). These effects have not been examined in gastropod larvae.

Some meroplanktonic taxa appear to respond to cues linked to predictable periodic cycles such as tidal states, diel periods or lunar phases. Some taxa (most notably crustaceans) vertically migrate in relation to tidal changes, possibly to enhance their transport away from estuaries and nearshore areas, and to return for settlement (Young 1995, DiBacco et al. 2001). Many larvae exhibit either a diel (towards the surface at night and deeper waters during the day) or a reverse-diel migration pattern (Daro 1974, Pennington \& Emlet 1986, Forward 1988, Garland et al. 2002, Poulin et al. 2002). Some larvae respond to lunar cues, which are generally linked to light intensity and/or tidal and diel cues (Manuel \& O'Dor 1997, Manuel et al. 1997). Vertical distributions of larval gastropods relative to tidal state and lunar phase have not been examined. Only a few studies have documented diel vertical migration in situ in gastropods, and the direction of migration varied among species (Daro 1974, Petipa 1955 as cited in Mileikovsky 1973, Garland et al. 2002, Poulin et al. 2002).

We describe changes in the vertical distribution of larval gastropods relative to structural changes of the water column in St. George's Bay, Nova Scotia, Canada, over a 36 and a $26 \mathrm{~h}$ period, during the full mon and the quarter moon, respectively. Specifically, we examined whether changes in larval vertical distribution varied: (1) with a suite of physical (temperature, salinity, current velocities) and biological (fluorescence as proxy for chlorophyll, i.e. phytoplankton) factors; and (2) over predictable cycles (lunar phase, diel period, and tidal state). By examining changes in larval vertical distribution for a variety of taxa with similar morphology and swimming abilities, but different nutritional and habitat requirements and lifehistory strategies, we can make suggestions about whether taxon-specific characteristics relate to differences in larval distributions in the water column.

\section{MATERIALS AND METHODS}

\section{Study site}

The study was conducted in St. George's Bay, Nova Scotia, Canada $\left(45^{\circ} 46^{\prime} \mathrm{N}, 61^{\circ} 43^{\prime} \mathrm{W}\right)$, a coastal embayment on the Northumberland Strait that is approximately $45 \times 45 \mathrm{~km}$. The tides in St. George's Bay are weak mixed diurnal to semidiurnal, with a tidal range from mean higher high water to mean lower low water of $\sim 1.5 \mathrm{~m}$ (Canadian Hydrographic Service, www.charts.gc.ca/twl-mne/index-eng.asp). The mean circulation in St. George's Bay is mainly clockwise, and only occasionally counter clockwise, and is hydrographically stable in the centre of the gyre (Petrie \& Drinkwater 1977). Variability associated with winds dominates the relatively weak mean circulation (Lesperance et al. 2011). In summer, the bay is generally vertically stratified, with a thermocline occurring at $\sim 10 \mathrm{~m}$ until October when mixing occurs (Petrie \& Drinkwater 1977). We used a single sampling location on the west side of the bay $\left(45^{\circ}\right.$ $46.98^{\prime} \mathrm{N}, 61^{\circ} 46.66^{\prime} \mathrm{W}$; depth $=25$ to $26.5 \mathrm{~m}$ ).

\section{Plankton sampling}

Plankton samples were collected with a cast iron, high volume $\left(\sim 0.85 \mathrm{~m}^{3} \mathrm{~min}^{-1}\right), 7.6 \mathrm{~cm}$ diameter por- 
table trash pump (Gorman-Rupp: Model 3S5HCR) with a 2-vane semi-open, $3.2 \mathrm{~cm}$ solid handling impeller. The pump was connected to a $27 \mathrm{~m}$ intake hose $(7.6 \mathrm{~cm}$ diameter) with a T-shaped head and a $5 \mathrm{~m}$ discharge hose. The discharge from the pump was directed into a submerged $200 \mu \mathrm{m}$ mesh plankton net to prevent damage to the larvae. Volume flow rates were determined by measuring the time required to fill a known volume at each sampling depth (0.94 and $0.75 \mathrm{~m}^{3} \mathrm{~min}^{-1}$, at 3 and $24 \mathrm{~m}$ respectively), and were used to standardize plankton abundance per unit volume. While sampling, the intake was moved vertically through a depth interval of $\sim 1 \mathrm{~m}$ for $5 \mathrm{~min}$, for a sample volume of $\sim 4.4 \mathrm{~m}^{3}$. Plankton were sampled at 3, 6, 9, 12, 18 and $24 \mathrm{~m}$ every $2 \mathrm{~h} \mathrm{(10:00,}$ $12: 00,14: 00,16: 00,18: 00,20: 00,22: 00,00: 00,02: 00$, 04:00, 06:00 and 08:00 h), over a period of $\sim 36(6-7$ August) or 26 h (12-13 August). Sampling depths were chosen to maximize sampling above and at the thermocline where larvae were expected to be found based on the literature, while still sampling the entire water column. The net and cod end were washed down with filtered seawater to concentrate larvae for preservation, and samples were preserved in $90 \%$ ethanol. Prior to sampling, water was pumped for a minimum of 2 min to clear the hose.

\section{Plankton sample processing}

In the laboratory, plankton were sorted, identified to the lowest possible taxon (using Thorson 1946, Scheltema 1962, Scheltema \& Scheltema 1965, ThiriotQuiévreux 1980, Thiriot-Quiévreux \& Scheltema 1982, Thiriot-Quiévreux 1983, Brunel et al. 1998, Shanks 2001), and enumerated using a Nikon SMZ 1500 dissecting microscope. Plankton samples were serially divided using a Folsom plankton splitter (Wildlife Supply Company), and entire subsamples (down to $1 / 16$, depending on larval abundance) sorted until either a minimum of 50 larvae of each taxon were counted or the entire sample was processed. For both sampling periods for each taxon at each sampling time and depth, larval abundance was calculated and standardized to number of larvae $\mathrm{m}^{-3}$. For the purpose of statistical analyses, the larval abundance for each gastropod taxon was normalized at each sampling time and depth using

$$
X_{i j}^{\prime}=\frac{X_{i j}-\mu}{\mathrm{SD}}
$$

where $X^{\prime}=$ normalized larval abundance at depth $i$ at time $j, X=$ larval abundance at depth $i$ at time $j, \mu=$ overall mean larval abundance across all depths and sampling times and both sampling periods, and $\mathrm{SD}=$ overall standard deviation in larval abundance across all depths and sampling times and both sampling periods.

\section{Sampling of physical characteristics}

Temperature, salinity, pressure, fluorescence, and current velocities (vertical $[w]$, north-south $[v]$ and east-west $[u]$ ) were measured in the water column, averaged to $1 \mathrm{~m}$ depth bins from 1 to $23-25 \mathrm{~m}$ depth, with a conductivity-temperature-depth (CTD) recorder (8 Hz, Seabird 25 CTD), a fluorometer $(8 \mathrm{~Hz}$, SCUFA fluorometer) and an acoustic Doppler current profiler $(600 \mathrm{kHz}$, Teledyne RDI Workhorse Sentinel ADCP, $\left.\pm 1 \mathrm{~cm} \mathrm{~s}^{-1}\right)$, respectively. Two profiler casts were made every 2 h over a 36 (6-7 August 2009) and a 26 h (12-13 August 2009) sampling period, associated with each sampling time. At the beginning of each sampling time, temperature, salinity, pressure and fluorescence were measured with a profiler (fluorometer attached to CTD) cast. The time between the end of Cast 1 and the start of Cast 2 was $\sim 5 \mathrm{~min}$. The profiler was then attached to the pump's T-shaped intake head, allowing for a second profiler cast for temperature and pressure measurements concurrent with plankton sampling. Some malfunctioning of the CTD (no record for temperature, salinity and pressure at 18:00 h on 6 August and 06:00 h and 08:00 h on 13 August, and salinity between 20:00 h on 6 August and 4:00 h on 7 August and 02:00 h on 13 August) and the fluorometer (12:00, 14:00, 16:00 and 18:00 h on 6 August, 00:00 and 02:00 h on 7 August, and 02:00, 04:00, 06:00, 08:00, 10:00, 12:00 14:00 and 16:00 h on 13 August) resulted in incomplete data sets. The ADCP was deployed on the seafloor, sampling 1-m depth bins from just above the bottom to just below the surface, recording 120 pings in a 2-min interval (measurement error $<1 \mathrm{~cm} \mathrm{~s}^{-1}$ ) every 20 min from 11 July to 22 August 2009. Velocities were recorded in east-west/north-south units. A chain of VEMCO thermistors was attached to the edge of the ADCP mooring, with thermistors approximately every $3 \mathrm{~m}$ from 3 to $24 \mathrm{~m}$ depth. The chain thermistors did not interfere with velocity calculations. The thermistors sampled every $20 \mathrm{~min}$, with a thermal lag of about 5 min to filter out high-frequency motions. Spectra showed very little evidence for high-frequency internal waves of periods $<1 \mathrm{~h}$. Light intensity was measured at the sea surface at the beginning of each plankton sampling time with a LI-COR Terrestrial Quantum Sensor (LI-190SA). 


\section{Profiler data processing}

For each profiler cast, only data collected during the down-casts were used and any outliers in temperature, salinity and fluorescence were identified using a moving average and removed. Temperature measurements were averaged between the 2 casts (before and during plankton sampling), unless the CTD failed to record during one of the casts. Temperature, salinity and fluorescence were averaged into $1 \mathrm{~m}$ depth bins, and density $\left(\sigma_{\mathrm{t}}, \mathrm{kg} \mathrm{m}^{-3}-1000\right)$ calculated for each depth using the state equation for seawater ('swstate' function for Matlab [The Mathworks Co.] developed by Woods Hole Science Center) for each sampling time. Vertical temperature gradients for each sampling time were calculated as $\Delta T / \Delta z$, where $T$ is temperature $\left({ }^{\circ} \mathrm{C}\right)$ and $z$ is depth $(\mathrm{m})$, at $1 \mathrm{~m}$ intervals. For each sampling time, the depth of the thermocline, in a vertically stratified water column, was identified as the first depth bin where the vertical temperature gradient over $1 \mathrm{~m}$ was $>0.5^{\circ} \mathrm{C} \mathrm{m}^{-1}$ (since variation in vertical temperature gradient in the mixed layer was minimal); and the depth of the fluorescence maximum was recorded.

\section{ADCP and thermistor data processing}

For both the ADCP and thermistor data, missing or unreliable data were either replaced by linearly interpolated values from surrounding points if there were sufficient data (typically 1 to 2 points) or were removed entirely. The ADCP current data from the upper $1 \mathrm{~m}$ of the water column were discarded due to side-lobe contamination of the signal from the surface. The current velocity components and the temperature data were filtered to ensure that they both exhibited the same spectral characteristics, removing high-frequency variability (of which there was relatively little) according to the method of Rabiner \& Gold (1975) implemented in Matlab, with a cut-off frequency of $2 \mathrm{~h}$. We analysed these averaged data for which the energy at periods below $2 \mathrm{~h}$ was removed.

\section{Statistical analyses}

We examined temporal correlation in larval abundance among sampling times with autocorrelation analyses on the mean depth distribution (MDD) of each gastropod taxon and sampling period using Matlab. This allowed us to determine the temporal lag at which autocorrelation was not significant and temporal dependency no longer present (Supplement 1 at www.int-res.com/articles/suppl/m464p135 _supp.pdf). This analysis revealed that the correlation among immediately adjacent ( $2 \mathrm{~h}$ lag) sampling times was not significant $(p>0.05)$ for all combinations of gastropod taxa, except Margarites spp. and Nudibranchia during the full moon, and Astyris lunata and Ilyanassa spp. during the quarter moon. Temporal dependency was absent by Lag 2 (i.e. $4 \mathrm{~h}$, every second sampling period) for Margarites spp., M. Iunata and Ilyanassa spp., and Lag 3 (i.e. 6 h, every third sampling period) for Nudibranchia. Based on these results, we concluded that sample autocorrelation was minimal when the entire suite of sampling times was considered, and treated sampling times as independent from one another.

We examined changes in the vertical distributions of larvae in response to lunar phase, diel period and tidal state, as manifested by the interaction terms between depth and diel period, lunar phase or tidal state, respectively. Depth-specific samples taken at different sampling times were pooled into 2 diel categories (day or night), and 4 tidal categories (ebb, flood, high or low). Based on sunset and sunrise times published by Environment Canada, we identified 18 day $(8: 00,10: 00,12: 00,14: 00,16: 00$ and 18:00 h) and 6 night $(22: 00,00: 00$ and 02:00 h) samples when sampling periods were combined. Samples collected at transition times were excluded (dusk: 20:00 h, and dawn: 4:00 and 6:00 h). There were 10 ebb (decreasing tidal height), 9 flood (increasing tidal height), 6 high tide, and 6 low tide samples when sampling periods were combined, as inferred from published tidal heights. Because there were not enough replicates to test the effects of all 4 factors (depth, tidal state, diel period, and lunar phase) simultaneously, we performed two 3-way analyses of variance (ANOVA) followed by Tukey's HSD post hoc tests to examine the effects on normalized larval abundance of: (1) lunar phase, diel period and depth; and (2) lunar phase, tidal state and depth. We examined the relationship between depth-specific normalized temperature (correlated to salinity, density, and Richardson number [Supplement 2 at www.int-res.com/articles/ suppl/m464p135_supp.pdf]), fluorescence, vertical velocity $(w)$, north-south velocity $(v)$ and east-west velocity $(u)$, and the depth-specific normalized larval abundance with simple and multiple (backward stepwise) regressions. The normalized larval abundance data were $\log (x+2)$ transformed to improve (but not successfully remove) normality and heterogeneity of variance as determined by examining the 
residuals. Given the large number of comparisons and statistical tests, we used $\alpha$-values of 0.01 for linear regressions and ANOVAs and 0.05 for Tukey's HSD as indicators of significance. A more conservative $\alpha$-value was used because of the large number of comparisons; however, the Bonferroni adjustment was considered too conservative $(\alpha$-value $=0.007)$, greatly increasing the probability of type II error, compared to other adjustment statistics. All correlations, linear regressions, ANOVA, and Tukey's HSD statistical analyses were conducted with SPSS 17.0.

\section{RESULTS}

\section{Physical structure of the water column}

The structure of the water column remained relatively consistent at the sampling station across the sampling period on both dates (Fig. 1). Temperature generally ranged between $\sim 20^{\circ} \mathrm{C}$ at the surface and $\sim 4^{\circ} \mathrm{C}$ at $25 \mathrm{~m}$, and salinity ranged between 29 and 31 . The water column was stratified, with the thermocline and pycnocline located at $\sim 10$ to $17 \mathrm{~m}$, respectively. Stratification in St. George's Bay is associated with summer warming. Fluorescence ranged between 0.09 and 0.35 , peaking between 13 and $18 \mathrm{~m}$ depth.

Overall, no clear circulation pattern was detected over a $43 \mathrm{~d}$ period in summer 2009 (11 July to 22 August), and mean currents within St. George's Bay were variable and tended to be depthdependent (Lesperance et al. 2011). This pattern is consistent with that found in an earlier study of the Bay (Petrie \& Drinkwater 1978). While Petrie and Drinkwater (1978) describe a clockwise circulation, both at the surface and near the bottom, their data and ours show substantial variability in the current field. The tides do provide regular forcing of the Bay, but wind forcing leads to quite variable circulation, typical of such a semi-enclosed coastal embayment. In general, mean current velocity

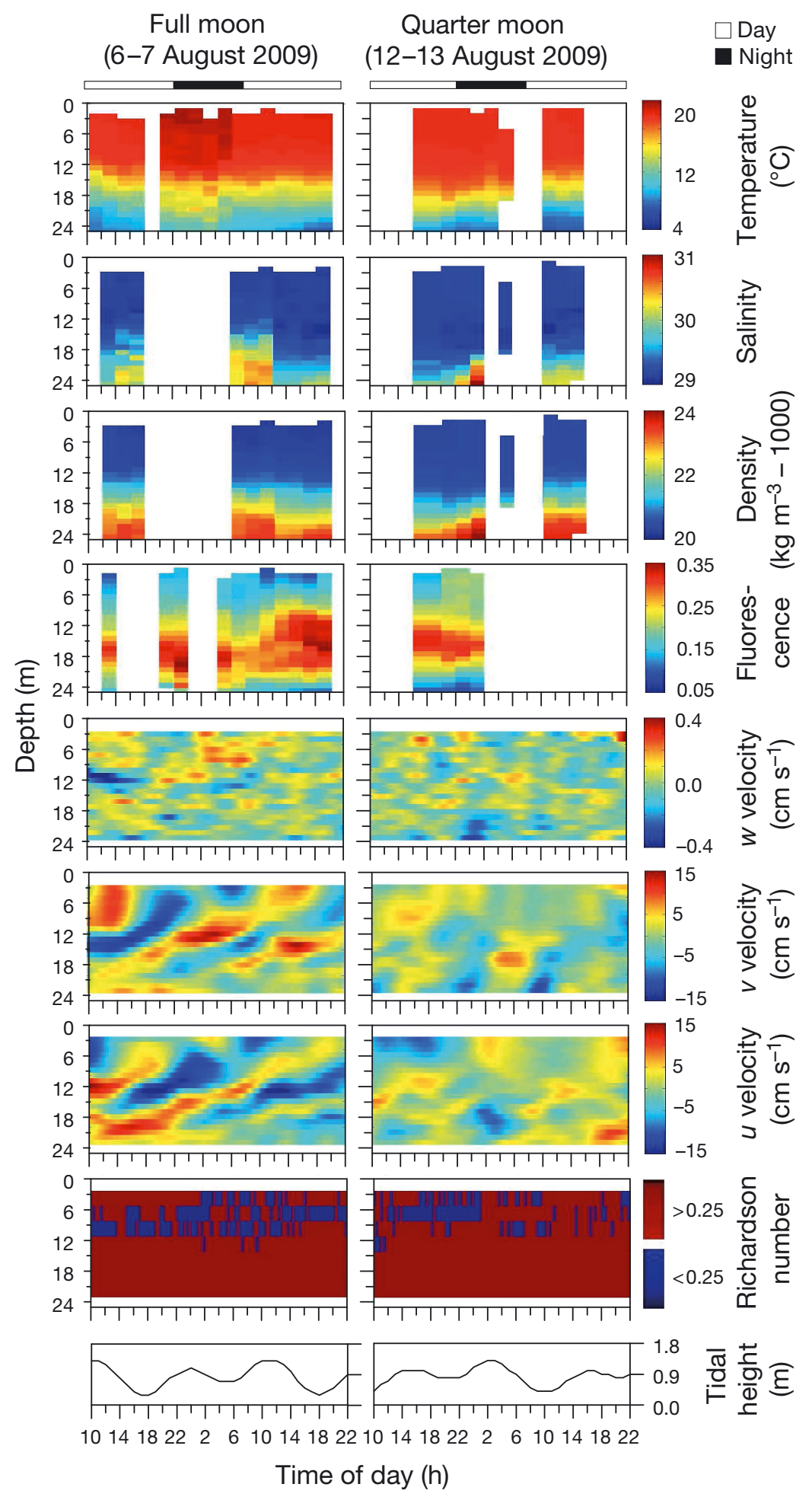

Fig. 1. Time series of the physical and biological variables measured at a single station $(z=25 \mathrm{~m})$ in St. George's Bay, Nova Scotia, Canada, over a 36- and 26-h period, during a spring (full moon: 6-7 August 2009) and neap (quarter moon: 12-13 August 2009) tide, respectively. CTD casts were made every $2 \mathrm{~h}$, and an acoustic Doppler current profiler moored on the sea floor sampled every $20 \mathrm{~min}$ (see 'Materials and methods' for details). White areas of the contour plots $=$ no data 
Table 1. Taxon-specific characteristics of planktonic larval gastropods found in St. George's Bay, Nova Scotia, Canada. Shell type: 1 = sinistrally coiled (counter clockwise), 2 = dextrally coiled (clockwise), $3=$ shell egg shaped. Developmental mode: $\mathrm{D}=$ direct, $\mathrm{L}=$ lecithotrophic, $\mathrm{P}=$ planktotrophic. Adult distribution: $\mathrm{I}=$ infralittoral $(0-20 \mathrm{~m}), \mathrm{C}=\operatorname{circa}$ littoral $(20-200 \mathrm{~m}), \mathrm{B}=$ bathyal (200-500 m), M = mediolittoral (intertidal). If no information was found for a certain species then information on other gastropod species within the genus or order was provided as denoted by the following superscripts: ${ }^{\mathrm{a}}=$ genus, $^{\mathrm{b}}=$ order. Sources: Lebour (1937), Thorson (1946), Scheltema \& Scheltema (1965), Thiriot-Quievreux \& Scheltema (1982), Strathmann (1987), Thiriot-Quievreux (1980), Brunel et al. (1998), and Collin (2001)

\begin{tabular}{|c|c|c|c|c|c|}
\hline Taxon & $\begin{array}{l}\text { Shell } \\
\text { type }\end{array}$ & $\begin{array}{l}\text { Length } \\
(\mu \mathrm{m})\end{array}$ & $\begin{array}{c}\text { Pelagic larval } \\
\text { duration }\end{array}$ & $\begin{array}{l}\text { Developmental } \\
\text { mode }\end{array}$ & $\begin{array}{c}\text { Adult } \\
\text { distribution }\end{array}$ \\
\hline Turbinidae: Margarites spp. & 1 & $180-400$ & Long & $\mathrm{P} / \mathrm{L} / \mathrm{D}^{\mathrm{a}}$ & $\mathrm{I}, \mathrm{C}, \mathrm{B}$ \\
\hline Calyptraeidae: Crepidula spp. & 2 & $200-960$ & $14+d$ & $\mathrm{P}$ & I, C \\
\hline Columbellidae: Astyris lunata & 2 & $240-880$ & Long & $\mathrm{P}^{\mathrm{a}}$ & I \\
\hline Diaphanidae: Diaphana minuta & 1 & $180-320$ & & $\mathrm{P}^{\mathrm{a}}$ & $\mathrm{C}, \mathrm{B}$ \\
\hline \multicolumn{6}{|l|}{ Littorinimorpha } \\
\hline Littorinidae: Lacuna vincta & 2 & & & $\mathrm{P}$ & M, I, C \\
\hline Littorinidae: Littorina littorea & 2 & $320-760$ & $14-21 \mathrm{~d}$ & $\mathrm{P}^{\mathrm{a}}$ & $M, I, C, B$ \\
\hline Naticidae: Lunata heros & 2 & $280-600$ & $31-54 \mathrm{~d}$ & $\mathrm{P} / \mathrm{L}^{\mathrm{a}}$ & I, C, B \\
\hline Aporrhaidae: Arrhoges occidentalis & 2 & $320-640$ & Long $^{\mathrm{a}}$ & & $\mathrm{I}, \mathrm{C}, \mathrm{B}$ \\
\hline Nassariidae: Ilyanassa spp. & 2 & $280-420$ & $14-29 \mathrm{~d}$ & $\mathrm{P}$ & M, I, C \\
\hline Cerithiidae: Bittiolum alternatum & 2 & $200-520$ & & & M, I \\
\hline Nudibranchia & 3 & $160-320$ & Long/short & $\mathrm{P} / \mathrm{L}^{\mathrm{b}}$ & $\mathrm{M}, \mathrm{I}, \mathrm{C}$ \\
\hline
\end{tabular}

was 5 times stronger in the mixed layer than at $20 \mathrm{~m}$ over a $43 \mathrm{~d}$ period at our sampling site in 2009, and flowed to the southwest and east, respectively (Lesperance et al. 2011). Horizontal current velocity was relatively weak $\left(<15 \mathrm{~cm} \mathrm{~s}^{-1}\right)$, but was stronger during the full than the quarter moon (Fig. 1). Consequently, shear was greater between depths during the full moon than quarter moon. During each period the weak horizontal currents began at depth and rose towards the surface over a period of hours (if tidal; 12-13 August) or a day (if wind-forced; 6-7 August). These velocities changed direction during tidal shifts, but the shift lag shows significant vertical structure. Vertical velocity was weak $\left(<0.2 \mathrm{~cm} \mathrm{~s}^{-1}\right)$ and variable, and patterns were likely due to noise (Fig. 1). Based on calculated Richardson numbers (Ri) (Supplement 3 at www.int-res.com/articles/suppl/m464 p135_supp.pdf), there was potential for instability $(R i<0.25)$ in the mixed layer of the water column, resulting in turbulent conditions, but below the thermocline, the water remained in a relatively stable state $(R i>0.25)$ (Fig. 1).

\section{General trends in gastropod larvae abundance}

We identified 9 gastropod taxa: Margarites spp., Crepidula spp., Astyris lunata, Diaphana minuta, Littorinimorpha (including the morphologically indistinguishable larvae of Littorina littorea, Lunata heros, and Lacuna vincta), Arrhoges occidentalis, Ilyanassa spp., Bittiolum alternatum, and Nudibranchia (see
Table 1 for taxonomic characteristics). Of these, Margarites spp. was the most abundant, accounting for 51 to $55 \%$ of total numerical abundance. The next 3 numerically most dominant taxa were Crepidula spp., A. lunata and D. minuta (5-17\%), while the remaining taxa composed $<3 \%$ of total abundance. Although the proportional abundance of each taxon remained relatively similar between sampling periods, larval depth-averaged concentration changed (Fig. 2). The depth-averaged concentrations of Margarites spp., D. minuta, A. occidentalis and Ilyanassa spp. increased between sampling periods, whereas that of Crepidula spp., A. lunata, Littorinimorpha, $B$. alternatum and Nudibranchia remained relatively unchanged (Fig. 2).

\section{Patterns in larval vertical distribution}

The larvae were not uniformly distributed in the water column (Fig. 3). Margarites spp. were present throughout the water column, but the greatest abundance was below the thermocline. Larvae of Littorinimorpha and Nudibranchia were mostly found below the thermocline, and those of Astyris lunata, Arrhoges occidentalis, Ilyanassa spp. and Bittiolum alternatum above the thermocline (Fig. 3). Lastly, the greatest abundances of Crepidula spp. and Diaphana minuta were near the thermocline ( 12 m) (Fig. 3). Littorinimorpha larvae were the only ones to be found in highest abundance around the fluorescence maximum at $18 \mathrm{~m}$ (Fig. 3). 


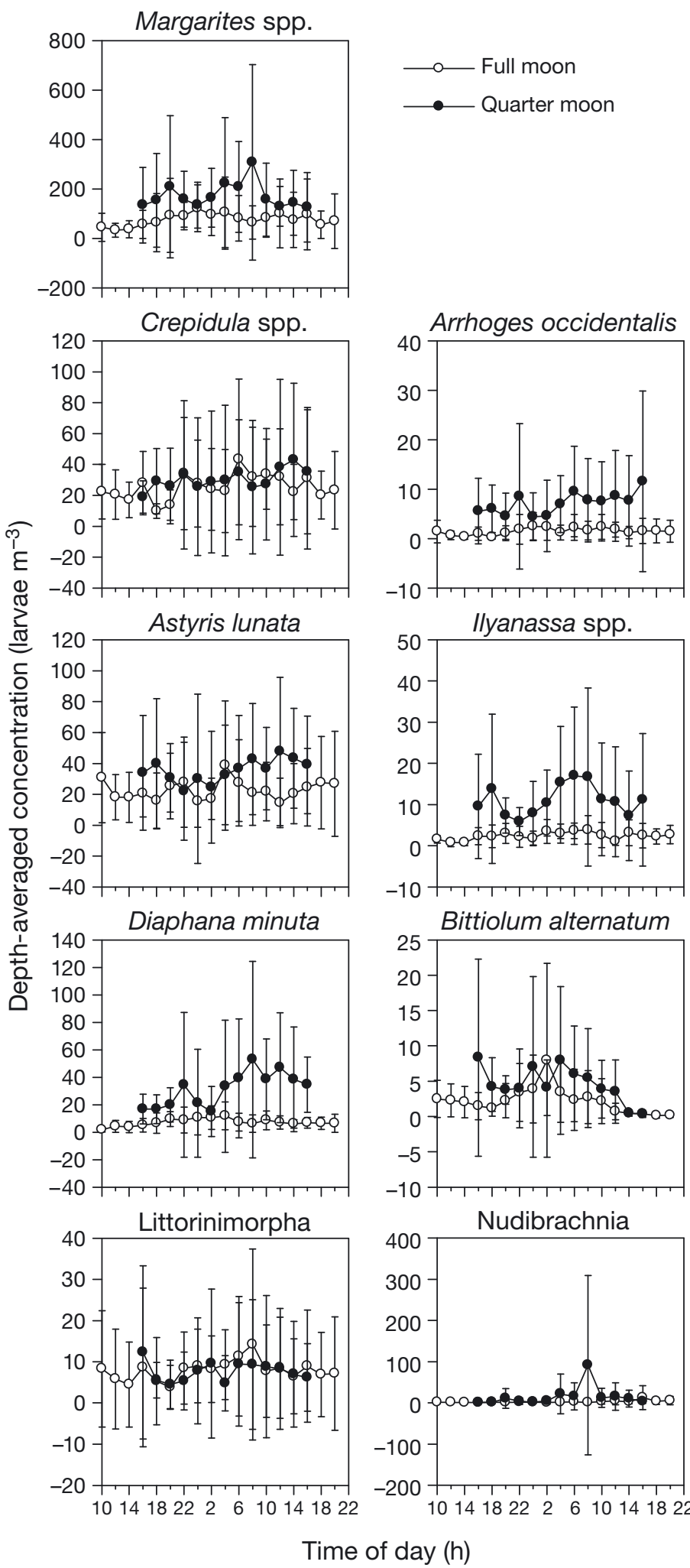

Fig. 2. Depth-averaged concentrations (mean $\pm \mathrm{SD}, \mathrm{n}=6$ ) of all identified taxa of gastropod larvae in St. George's Bay, Nova Scotia, Canada, over a 36 and a 26 h sampling period, during a spring (full moon: 6-7 August 2009) and neap (quarter moon: 12-13 August 2009) tide, respectively
The vertical distributions of most larvae were primarily related to temperature, salinity and density, except for Littorinimorpha and Crepidula spp. for which most of the variance was explained by fluorescence (Fig. 3a, Table 2). The abundances of Margarites spp., Littorinimorpha and Nudibranchia were negatively related to temperature (Table 2), whereas those of Crepidula spp., Astyris lunata, Diaphana minuta, Arrhoges occidentalis, Ilyanassa spp. and Bittiolum alternatum were positively related to temperature (Table 2). The opposite patterns were recorded for salinity and density, which correlated significantly with temperature (Supplement 2). The abundance of Littorinimorpha showed a quadratic relationship with temperature, which was stronger than the linear one, with low abundance at both low and high temperatures $\left(\mathrm{R}^{2}\right.$ adj $=0.681, F_{(2,160)}=174.0$, $\mathrm{p}<0.001)$.

The vertical distributions of several taxa (Crepidula spp., Astyris lunata, Diaphana minuta, Littorinimorpha and Nudibranchia) were linearly related to fluorescence, potentially a signal of food; however, a large proportion of variance in abundance was explained by fluorescence only for Crepidula spp. and Littorinimorpha (Fig. 3b, Table 2). The abundance of Margarites spp. and Nudibranchia showed significant, although weak, quadratic relationships with fluorescence, where abundance was higher at both low and high fluorescence (Margarites spp.: $\mathrm{R}_{\text {adj }}^{2}=0.161, F_{(2,98)}=10.63, \mathrm{p}<0.001$; and Nudibranchia: $\left.\mathrm{R}^{2}{ }_{\text {adj }}=0.229, F_{(2,98)}=15.89, \mathrm{p}<0.001\right)$.

Unlike temperature and fluorescence, current ( $u, v$, $w)$ velocity did not explain any of the variation in the abundance for many gastropod taxa, except Bittiolum alternatum. Even for B. alternatum, only a small percentage of the variation was explained by a negative relationship with $u$ (Table 2).

In some cases, a larger proportion of the variance in larval abundance was explained when a combination of factors (temperature, fluorescence, $u$ ) was included (Table 2). Of all gastropod taxa, only the variation in the abundance of Crepidula spp., Diaphana minuta, Littorinimorpha and Nudibranchia was better explained by a combination of temperature and fluorescence than by a single factor (Table 2).

\section{Periodicity in larval vertical distribution}

The distributions of 4 gastropod taxa (Margarites spp., Astyris lunata, Ilyanassa spp., Bittiolum alternatum) varied dielly (Fig. 4, Table 3), some during only 

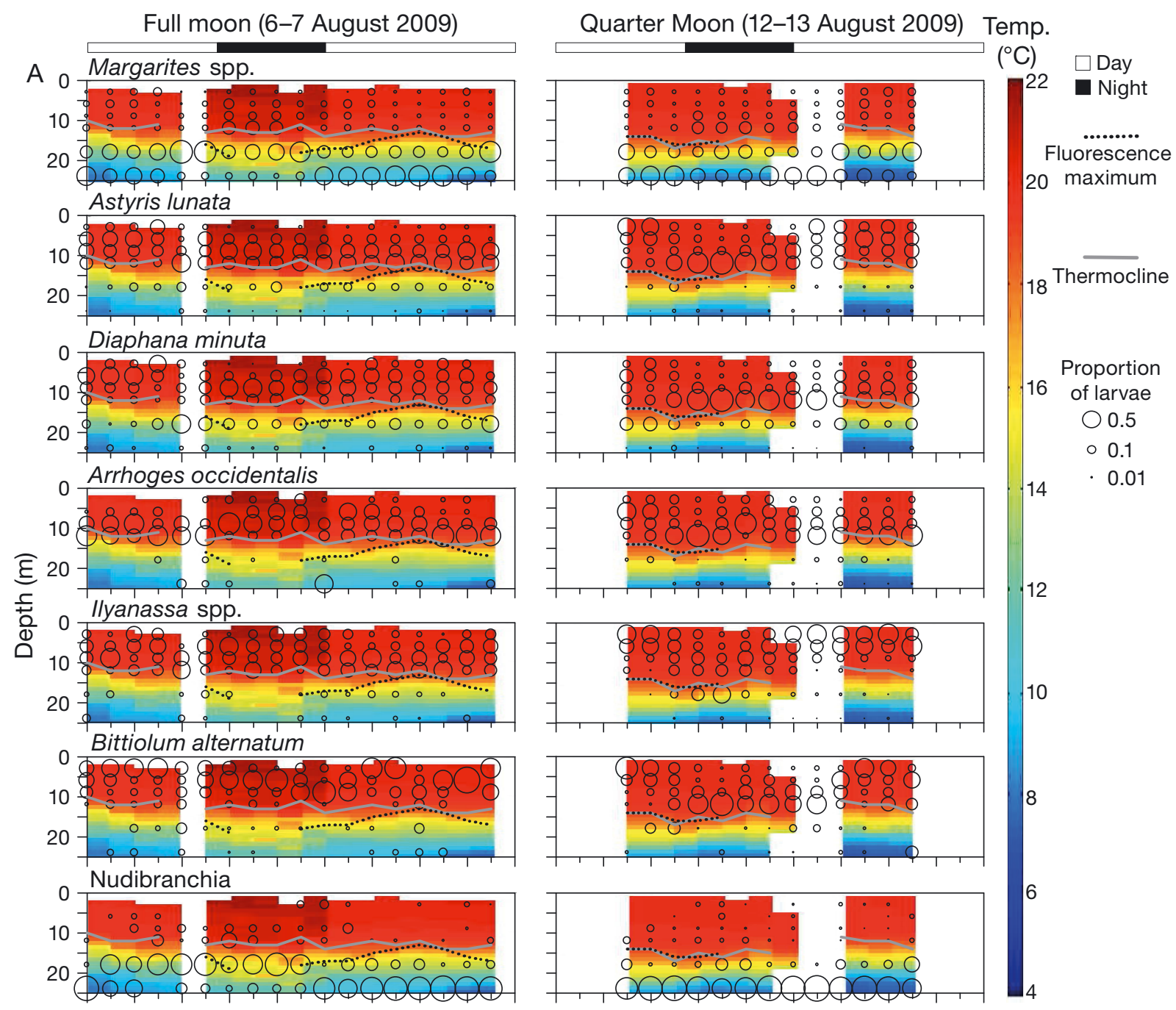

Proportion

16 of larvae

0.5

$\circ 0.1$

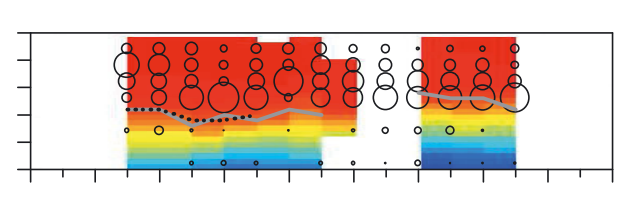

$14 \cdot 0.01$
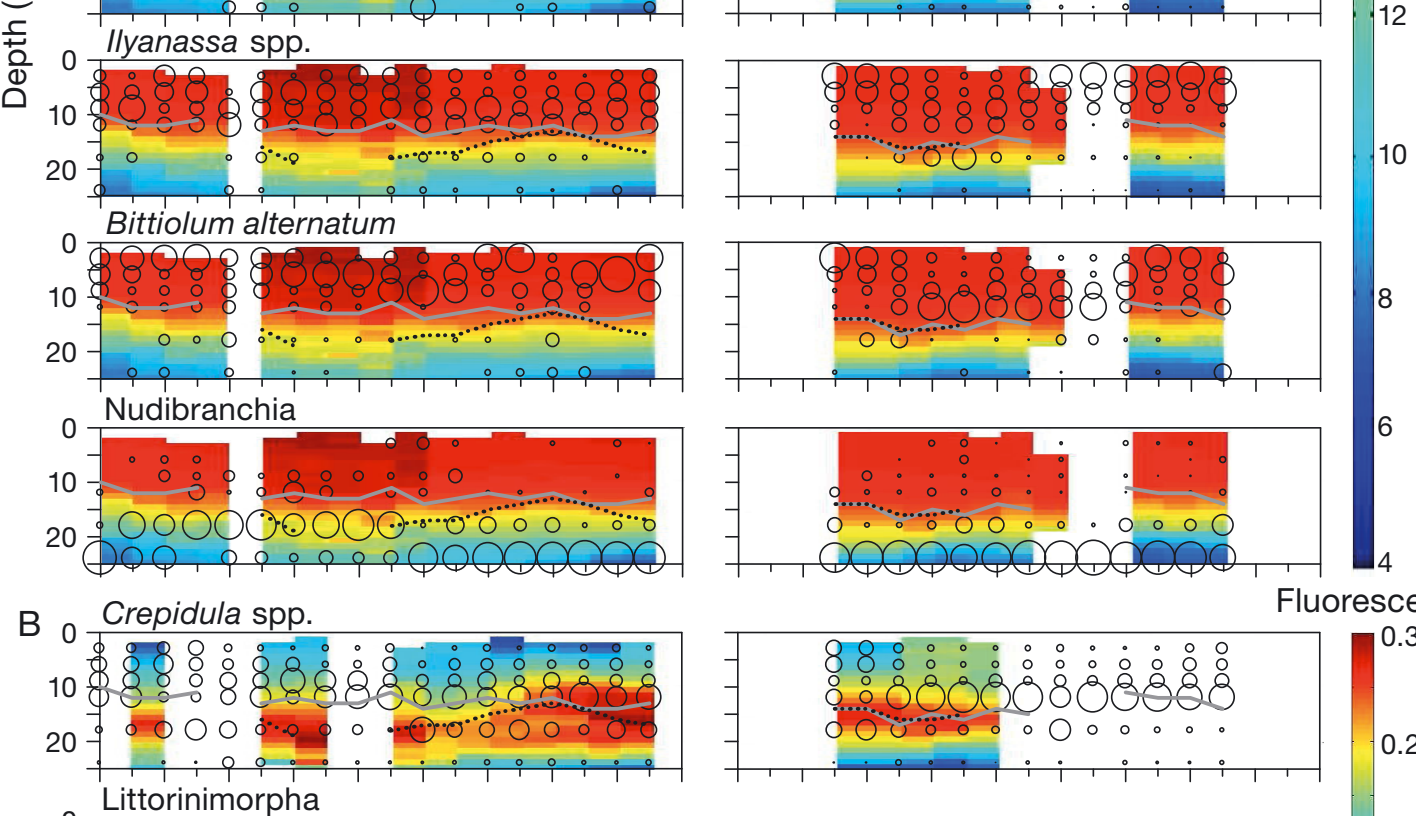

Fluorescence
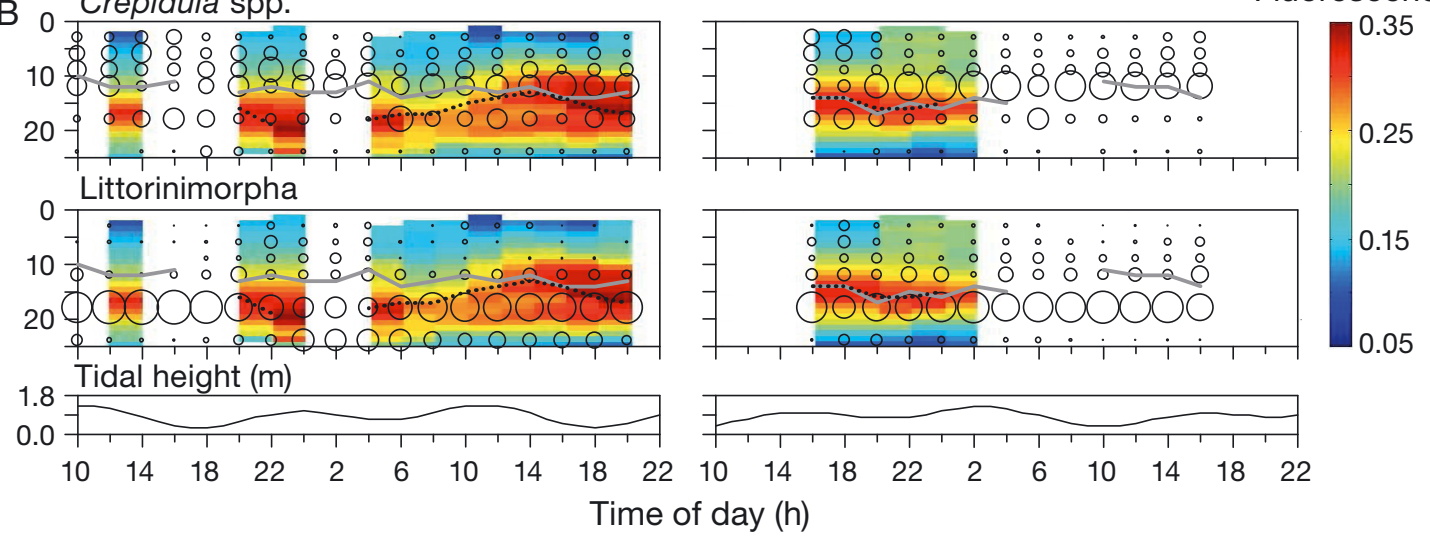

Fig. 3. Vertical distribution of all identified gastropod larvae, in St. George's Bay, Nova Scotia, Canada, over a 36- and 26-h period, during a spring (full moon: 6-7 August 2009) and neap (quarter moon: 12-13 August 2009) tide, respectively. The proportional abundance of gastropod larvae was calculated at each depth interval (i.e. 3, 6, 9, 12, 18 or $24 \mathrm{~m}$ ) for each sampling time $j$ using $P_{i j}=n_{i j} / N_{j}$ where $P_{i j}=$ proportional abundance at depth interval $i$ at time $j, n_{i j}=$ number of larvae collected at depth $i$ at time $j$, and $N_{j}=$ total number of larvae sampled at time $j$. The proportional abundance was used to standardize larval concentrations for each taxon within and among sampling periods. Circle size is proportional to the abundance of larvae for a particular sampling time (legend provides a size reference for the proportion of larvae found at each depth). The colored contours represent either (A) temperature (Margarites spp., Astyris lunata, Diaphana minuta, Arrhoges occidentalis, Ilyanassa spp., Bittiolum alternatum and Nudibranchia), (or B) fluorescence (Crepidula spp. and Littorinimorpha). Only the dominant factors are shown for each gastropod taxon, as determined by simple linear regressions 
Table 2. Simple and multiple (backwards stepwise) linear regression explaining patterns in the normalized larval abundance of different gastropod taxa in relation to different normalized physical and biological variables. $T=$ temperature, $S=$ salinity, $\sigma_{t}$ $=$ density, $F l=$ fluorescence, $w=$ vertical velocity, $v=$ north-south velocity, $u=$ east-west velocity; $-/+=$ negative or positive relationship; $\mathrm{ns}=$ not significant $(\mathrm{p}>0.01)$; degrees of freedom for each regression are shown in parentheses below each variable

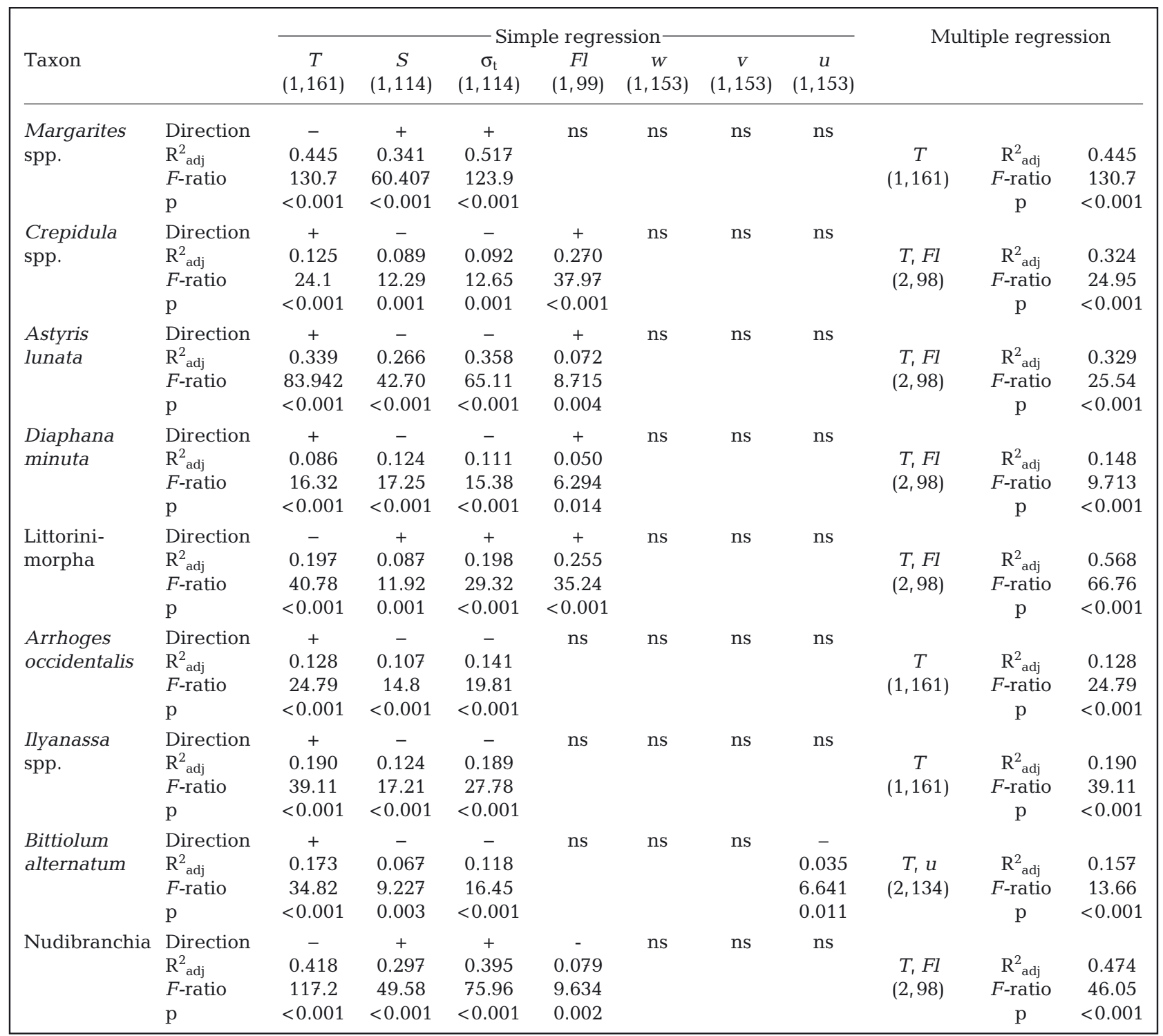

1 lunar phase, as indicated by a lunar phase $\times$ diel period $\times$ depth interaction (Table 3). The distribution of Margarites spp. appeared to vary dielly during both lunar phases (Fig. 4). The highest abundance of Margarites spp. was found shallower (full moon: 3-24 m, quarter moon: 6-24 m) at night than during the day (full moon: $24 \mathrm{~m}$, quarter moon: 18-24 m), during both lunar phases (Fig. 4, Tables $3 \& 4$ ). The vertical distribution of A. lunata, Ilyanassa spp., and $B$. alternatum showed a reverse pattern, but only during 1 lunar phase. All these taxa were deeper at night (12 m, 9-18 $\mathrm{m}$ and $12 \mathrm{~m}$, respectively) than dur- ing the day (3-6 $\mathrm{m}, 3-6 \mathrm{~m}$ and $3 \mathrm{~m}$, respectively) during the quarter moon (Fig. 4, Tables $3 \& 4$ ). During the full moon, the larval distributions of A. lunata, Ilyanassa spp. and $B$. alternatum were similar during the day and night, except for $B$. alternatum, which was significantly more abundant at $6 \mathrm{~m}$ at night than during the day (Fig. 4, Tables $3 \& 4$ ).

The vertical distribution of Crepidula spp., Littorinimorpha, Arrhoges occidentalis and Nudibranchia varied only with lunar phase (i.e. no significant interactions with diel period or tidal state) (Fig. 5). For Crepidula spp. and Littorinimorpha, the highest 


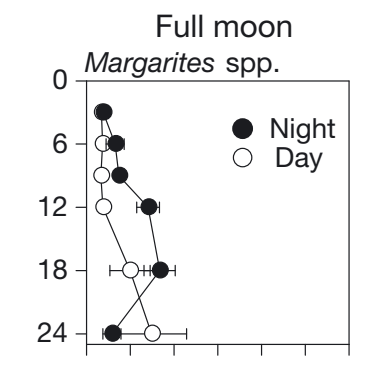

Quarter moon
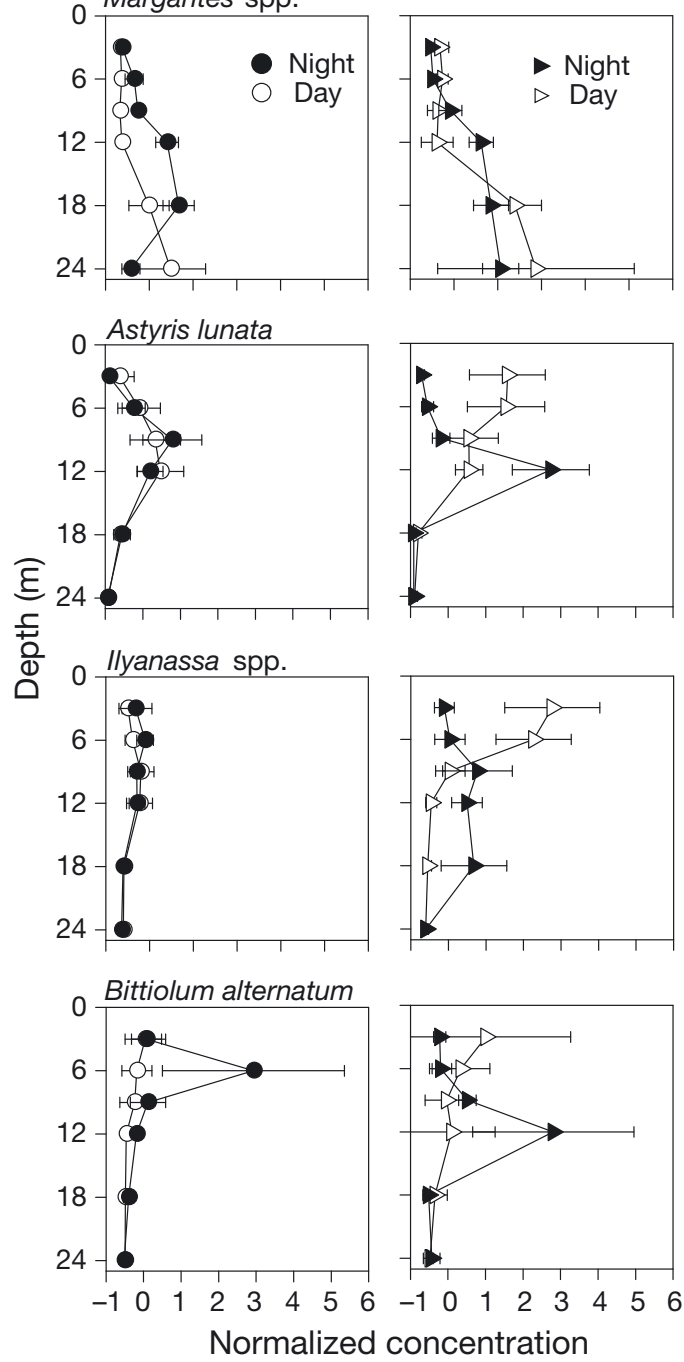

Fig. 4. Margarites spp, Astyris lunata, Ilyanassa spp., Bittiolum alternatum. Vertical distribution of gastropod larvae, at each of 2 diel periods and 2 lunar phases (mean $\pm \mathrm{SD}, \mathrm{n}=$ 3-11) in St. George's Bay, Nova Scotia, Canada

abundance was found predominantly at $12 \mathrm{~m}$ and 18 $\mathrm{m}$, respectively, during both lunar phases. However, their distribution was broader during the full moon (full moon; 9-18 m, quarter moon: 18-24 m) (Fig. 5, Tables 3 to 6). In comparison, the abundance of $A$. occidentalis and Nudibranchia peaked at $12 \mathrm{~m}$ and $24 \mathrm{~m}$, respectively, during the quarter moon, and these larvae were evenly distributed during the full moon (Fig. 5, Tables 3 to 6).

Margarites spp., Diaphana minuta and Ilyanassa spp. were the only gastropod taxa for which vertical distribution varied with tidal state during at least 1 lunar phase, as indicated by a lunar phase $\times$ tidal state $\times$ depth interaction (Fig. 6, Table 5). In general, Margarites spp. was most abundant at $24 \mathrm{~m}$ during

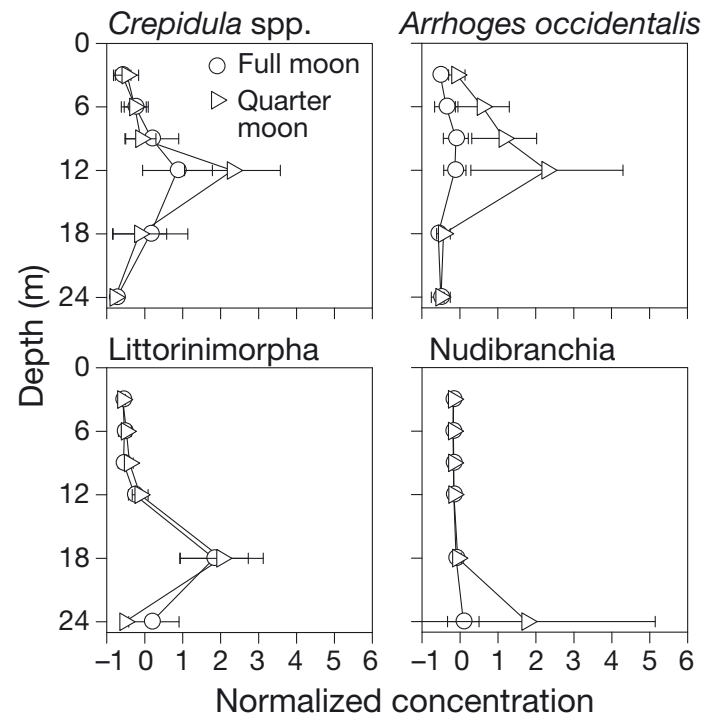

Fig. 5. Crepidula spp., Arrhoges occidentalis, Littorinimorpha, Nudibranchia. Vertical distribution of gastropod larvae with a significant interaction between depth and lunar phase (mean $\pm \mathrm{SD}, \mathrm{n}=13-18$ ) in St. George's Bay, Nova Scotia, Canada

the ebb and slightly shallower $(<24 \mathrm{~m})$ during flood, low and high tides (Fig. 6, Table 5), during both lunar phases. In contrast, the vertical distribution of $D$. minuta and Ilyanassa spp. only varied with tidal state during the quarter moon (Fig. 6, Tables $5 \& 6$ ). $D$. minuta was most abundant between 9 and $12 \mathrm{~m}$ during ebb and flood and evenly distributed ( 3-18 m) during high and low tides, while Ilyanassa spp. was shallower during flood $(3 \mathrm{~m})$ than during ebb, high and low $(\sim 6 \mathrm{~m})$ tides (Fig. 6 , Tables $5 \& 6$ ).

\section{DISCUSSION}

\section{Patterns in larval vertical distribution}

In this study, the vertical distribution of gastropod larvae was strongly related to physical and biological features of the water column. The thermocline, in particular, strongly influenced the distributions of most taxa. Because the density structure of the water column was primarily a function of temperature, temperature accounted for most of the variation in larval abundance for most taxa. The presence of larvae in a particular water layer may be the result of changes in their buoyancy and changes in water density (Tremblay \& Sinclair 1990, Gallager et al. 1996). The role of buoyancy in the vertical distribution of gastropod larvae is not known. However, bivalve (e.g. giant scallop Placopecten magellanicus) larvae in stratified regions tend to aggregate around the pycnocline, 
Table 3. Analysis of variance (ANOVA) examining the effect of lunar phase (full moon, quarter moon), diel period (day, night), and depth $(3,6,9,12,18$ and $24 \mathrm{~m})$ on the normalized abundance for all identified gastropod larvae $(\alpha=0.01$, significant $\mathrm{p}$-values indicated in bold, error $\mathrm{df}=120$ )

\begin{tabular}{|c|c|c|c|c|c|c|c|c|}
\hline Taxon & $\begin{array}{l}\text { Source } \\
\text { df }\end{array}$ & $\begin{array}{c}\text { Lunar phase }(L) \\
1\end{array}$ & $\begin{array}{c}\text { Diel period }(D) \\
1\end{array}$ & $\begin{array}{c}\text { Depth }(z) \\
5\end{array}$ & $\begin{array}{c}L \times D \\
1\end{array}$ & $\begin{array}{l}L \times Z \\
5\end{array}$ & $\begin{array}{c}D \times z \\
5\end{array}$ & $\begin{array}{c}L \times \underset{5}{D} \times Z \\
\end{array}$ \\
\hline Margarites spp. & $\begin{array}{l}\text { F-ratio } \\
\mathrm{p}\end{array}$ & $\begin{array}{c}18.47 \\
<\mathbf{0 . 0 0 1}\end{array}$ & $\begin{array}{l}0.552 \\
0.459\end{array}$ & $\begin{array}{c}16.14 \\
<\mathbf{0 . 0 0 1}\end{array}$ & $\begin{array}{l}2.089 \\
0.151\end{array}$ & $\begin{array}{l}3.198 \\
\mathbf{0 . 0 1 0}\end{array}$ & $\begin{array}{l}4.496 \\
\mathbf{0 . 0 0 1}\end{array}$ & $\begin{array}{l}0.693 \\
0.630\end{array}$ \\
\hline Crepidula spp. & $\begin{array}{l}F \text {-ratio } \\
\mathrm{p}\end{array}$ & $\begin{array}{l}0.971 \\
0.326\end{array}$ & $\begin{array}{l}0.102 \\
0.751\end{array}$ & $\begin{array}{c}39.71 \\
<\mathbf{0 . 0 0 1}\end{array}$ & $\begin{array}{l}0.657 \\
0.419\end{array}$ & $\begin{array}{l}8.858 \\
<\mathbf{0 . 0 0 1}\end{array}$ & $\begin{array}{l}1.912 \\
0.097\end{array}$ & $\begin{array}{l}2.075 \\
0.073\end{array}$ \\
\hline Astyris lunata & $\begin{array}{l}\text { F-ratio } \\
\mathrm{p}\end{array}$ & $\begin{array}{c}16.91 \\
<\mathbf{0 . 0 0 1}\end{array}$ & $\begin{array}{l}7.102 \\
\mathbf{0 . 0 0 9}\end{array}$ & $\begin{array}{c}31.15 \\
<\mathbf{0 . 0 0 1}\end{array}$ & $\begin{array}{l}5.362 \\
0.022\end{array}$ & $\begin{array}{c}8.512 \\
<\mathbf{0 . 0 0 1}\end{array}$ & $\begin{array}{c}10.41 \\
<\mathbf{0 . 0 0 1}\end{array}$ & $\begin{array}{c}10.78 \\
<\mathbf{0 . 0 0 1}\end{array}$ \\
\hline Diaphana minuta & $\begin{array}{l}\text { F-ratio } \\
\mathrm{p}\end{array}$ & $\begin{array}{c}42.26 \\
<\mathbf{0 . 0 0 1}\end{array}$ & $\begin{array}{l}1.197 \\
0.276\end{array}$ & $\begin{array}{c}17.57 \\
<\mathbf{0 . 0 0 1}\end{array}$ & $\begin{array}{l}5.729 \\
0.018\end{array}$ & $\begin{array}{l}13.45 \\
<\mathbf{0 . 0 0 1}\end{array}$ & $\begin{array}{l}1.408 \\
0.226\end{array}$ & $\begin{array}{l}1.116 \\
0.356\end{array}$ \\
\hline Littorinimorpha & $\begin{array}{l}\text { F-ratio } \\
\mathrm{p}\end{array}$ & $\begin{array}{l}0.057 \\
0.812\end{array}$ & $\begin{array}{l}0.006 \\
0.937\end{array}$ & $\begin{array}{l}80.265 \\
<\mathbf{0 . 0 0 1}\end{array}$ & $\begin{array}{l}0.463 \\
0.497\end{array}$ & $\begin{array}{l}4.452 \\
\mathbf{0 . 0 0 1}\end{array}$ & $\begin{array}{l}2.720 \\
0.023\end{array}$ & $\begin{array}{l}1.618 \\
0.160\end{array}$ \\
\hline Arrhoges occidentalis & $\begin{array}{l}\text { F-ratio } \\
\mathrm{p}\end{array}$ & $\begin{array}{l}33.55 \\
<\mathbf{0 . 0 0 1}\end{array}$ & $\begin{array}{l}0.308 \\
0.580\end{array}$ & $\begin{array}{c}16.13 \\
<\mathbf{0 . 0 0 1}\end{array}$ & $\begin{array}{l}2.898 \\
0.091\end{array}$ & $\begin{array}{l}8.154 \\
<\mathbf{0 . 0 0 1}\end{array}$ & $\begin{array}{l}0.382 \\
0.860\end{array}$ & $\begin{array}{l}0.486 \\
0.786\end{array}$ \\
\hline Ilyanassa spp. & $\begin{array}{l}\text { F-ratio } \\
\mathrm{p}\end{array}$ & $\begin{array}{l}84.45 \\
<\mathbf{0 . 0 0 1}\end{array}$ & $\begin{array}{l}3.575 \\
0.061\end{array}$ & $\begin{array}{c}15.89 \\
<\mathbf{0 . 0 0 1}\end{array}$ & $\begin{array}{c}5.579 \\
<\mathbf{0 . 0 0 1}\end{array}$ & $\begin{array}{c}9.755 \\
<\mathbf{0 . 0 0 1}\end{array}$ & $\begin{aligned} & 14.8 \\
< & \mathbf{0 . 0 0 1}\end{aligned}$ & $\begin{array}{c}20.15 \\
<\mathbf{0 . 0 0 1}\end{array}$ \\
\hline Bittiolum alternatum & $\begin{array}{l}\text { F-ratio } \\
\mathrm{p}\end{array}$ & $\begin{array}{l}1.660 \\
0.200\end{array}$ & $\begin{array}{l}8.143 \\
\mathbf{0 . 0 0 5}\end{array}$ & $\begin{array}{c}7.243 \\
<\mathbf{0 . 0 0 1}\end{array}$ & $\begin{array}{l}1.863 \\
0.175\end{array}$ & $\begin{array}{c}7.000 \\
<\mathbf{0 . 0 0 1}\end{array}$ & $\begin{array}{c}4.814 \\
<\mathbf{0 . 0 0 1}\end{array}$ & $\begin{array}{c}7.234 \\
<\mathbf{0 . 0 0 1}\end{array}$ \\
\hline Nudibranchia & $\begin{array}{l}\text { F-ratio } \\
\mathrm{p}\end{array}$ & $\begin{array}{l}1.227 \\
0.270\end{array}$ & $\begin{array}{l}1.073 \\
0.302\end{array}$ & $\begin{array}{l}1.787 \\
0.121\end{array}$ & $\begin{array}{l}0.679 \\
0.411\end{array}$ & $\begin{array}{l}1.118 \\
0.354\end{array}$ & $\begin{array}{l}1.099 \\
0.365\end{array}$ & $\begin{array}{l}0.579 \\
0.716\end{array}$ \\
\hline
\end{tabular}

Table 4. Statistically significant results of post hoc multiple comparisons (Tukey's HSD test) for the 3-way ANOVAs (Table 3) that identified significant differences between depth $(z)$, and either diel period $(D)$ and/or lunar phase $(L)$. Numbers represent depths $(3,6,9,12,18$ and $24 \mathrm{~m})$. Only significant differences of larval abundance among depths are shown. Depths, separated by commas, are ordered sequentially ( 3 to $24 \mathrm{~m}$ ), not according to relative larval abundance at each depth. ns = no significant difference among depths

\begin{tabular}{|c|c|c|c|}
\hline Taxon & $\begin{array}{l}\text { Significant factor }(L, D, z) \\
\text { interaction terms }\end{array}$ & $\begin{array}{l}\text { Factor levels } \\
\qquad(L-D)\end{array}$ & $\begin{array}{l}\text { Multiple comparisons } \\
\text { of larval abundance among depths }(z)\end{array}$ \\
\hline Margarites spp. & $L \times D \times z$ & $\begin{array}{l}\text { Full moon - day } \\
\text { Full moon - night } \\
\text { Quarter moon - day } \\
\text { Quarter moon - night }\end{array}$ & $\begin{array}{l}3,6,9,12<24 \\
\text { ns } \\
3,6,9,12<18,24 \\
3,6<24\end{array}$ \\
\hline Astyris lunata & $L \times D \times z$ & $\begin{array}{l}\text { Full moon - day } \\
\text { Full moon - night } \\
\text { Quarter moon - day } \\
\text { Quarter moon - night }\end{array}$ & $\begin{array}{l}3,18,24<9,12 ; 24<6 \\
3,18,24<9 \\
9,12,18,24<3,6 ; 18,24<9,12 \\
3,6,9,18,24<12\end{array}$ \\
\hline Ilyanassa spp. & $L \times D \times z$ & $\begin{array}{l}\text { Full moon - day } \\
\text { Full moon - night } \\
\text { Quarter moon - day } \\
\text { Quarter moon - night }\end{array}$ & $\begin{array}{l}\text { ns } \\
\text { ns } \\
9,12,18,24<3,6 \\
24<9,12,18\end{array}$ \\
\hline Bittiolum alternatum & $L \times D \times z$ & $\begin{array}{l}\text { Full moon - day } \\
\text { Full moon - night } \\
\text { Quarter moon - day } \\
\text { Quarter moon - night }\end{array}$ & $\begin{array}{l}\text { ns } \\
3,9,12,18,24<6 \\
18,24<3 \\
3,6,9,18,24<12\end{array}$ \\
\hline Crepidula spp. & $L \times z$ & $\begin{array}{l}\text { Full moon } \\
\text { Quarter moon }\end{array}$ & $\begin{array}{l}3,6,18,24<12 ; 3,24<9 ; 24<18 \\
3,6,9,18,24<12\end{array}$ \\
\hline Diaphana minuta & $L \times z$ & $\begin{array}{l}\text { Full moon } \\
\text { Quarter moon }\end{array}$ & $\begin{array}{l}\mathrm{ns} \\
3,6,9,18,24<12 ; 3,24<9 ; 24<6,18\end{array}$ \\
\hline Littorinimorpha & $L \times z$ & $\begin{array}{l}\text { Full moon } \\
\text { Quarter moon }\end{array}$ & $\begin{array}{l}3,6,9,12,24<18 ; 3,6,9<24 \\
3,6,9,12,24<18\end{array}$ \\
\hline Arrhoges occidentalis & $L \times z$ & $\begin{array}{l}\text { Full moon } \\
\text { Quarter moon }\end{array}$ & $\begin{array}{l}\text { ns } \\
3,6,9,18,24<12 ; 3,18,24<9 ; 18,24<6\end{array}$ \\
\hline
\end{tabular}


Table 5. Three-way ANOVA examining the effect of lunar phase (full moon, quarter moon), tidal state (ebb, flood, high, low), and depth $(3,6,9,12,18$ and $24 \mathrm{~m})$ on the normalized abundance for all identified gastropod larvae $(\alpha=0.01$, significant $\mathrm{p}$-values indicated in bold, error $\mathrm{df}=138$ )

\begin{tabular}{|c|c|c|c|c|c|c|c|c|}
\hline Taxon & $\begin{array}{l}\text { Source } \\
\text { df }\end{array}$ & $\begin{array}{c}\text { Lunar phase }(L) \\
1\end{array}$ & $\begin{array}{c}\text { Tidal state }(T i) \\
3\end{array}$ & $\begin{array}{l}\text { Depth }(z) \\
5\end{array}$ & $\begin{array}{c}L \times T i \\
3\end{array}$ & $\begin{array}{c}L \times z \\
5\end{array}$ & $\begin{array}{c}T i \times z \\
15\end{array}$ & $\begin{array}{c}L \times T i \times z \\
15\end{array}$ \\
\hline Margarites spp. & $\begin{array}{l}\text { F-ratio } \\
\mathrm{p}\end{array}$ & $\begin{array}{c}55.86 \\
<\mathbf{0 . 0 0 1}\end{array}$ & $\begin{array}{l}2.287 \\
0.081\end{array}$ & $\begin{array}{c}48.51 \\
<\mathbf{0 . 0 0 1}\end{array}$ & $\begin{array}{l}3.491 \\
0.017\end{array}$ & $\begin{array}{c}9.958 \\
<\mathbf{0 . 0 0 1}\end{array}$ & $\begin{array}{r}4.365 \\
<\mathbf{0 . 0 0 1}\end{array}$ & $\begin{array}{l}2.313 \\
\mathbf{0 . 0 0 6}\end{array}$ \\
\hline Crepidula spp. & $\begin{array}{l}F \text {-ratio } \\
\mathrm{p}\end{array}$ & $\begin{array}{l}1.896 \\
0.171\end{array}$ & $\begin{array}{l}1.343 \\
0.263\end{array}$ & $\begin{array}{c}44.55 \\
<\mathbf{0 . 0 0 1}\end{array}$ & $\begin{array}{l}0.215 \\
0.886\end{array}$ & $\begin{array}{l}7.042 \\
<\mathbf{0 . 0 0 1}\end{array}$ & $\begin{array}{l}1.064 \\
0.396\end{array}$ & $\begin{array}{l}1.109 \\
0.354\end{array}$ \\
\hline Astyris lunata & $\begin{array}{l}\text { F-ratio } \\
\mathrm{p}\end{array}$ & $\begin{array}{c}12.588 \\
\mathbf{0 . 0 0 1}\end{array}$ & $\begin{array}{l}0.187 \\
0.905\end{array}$ & $\begin{array}{l}26.347 \\
<\mathbf{0 . 0 0 1}\end{array}$ & $\begin{array}{l}0.689 \\
0.560\end{array}$ & $\begin{array}{l}4.476 \\
\mathbf{0 . 0 0 1}\end{array}$ & $\begin{array}{l}0.484 \\
0.945\end{array}$ & $\begin{array}{l}0.444 \\
0.963\end{array}$ \\
\hline Diaphana minuta & $\begin{array}{l}\text { F-ratio } \\
\mathrm{p}\end{array}$ & $\begin{array}{c}98.28 \\
<\mathbf{0 . 0 0 1}\end{array}$ & $\begin{array}{l}1.787 \\
0.153\end{array}$ & $\begin{array}{c}25.87 \\
<\mathbf{0 . 0 0 1}\end{array}$ & $\begin{array}{l}1.849 \\
0.141\end{array}$ & $\begin{array}{l}21.29 \\
<\mathbf{0 . 0 0 1}\end{array}$ & $\begin{array}{l}2.223 \\
\mathbf{0 . 0 0 8}\end{array}$ & $\begin{array}{l}1.895 \\
0.028\end{array}$ \\
\hline Littorinimorpha & $\begin{array}{l}\text { F-ratio } \\
\mathrm{p}\end{array}$ & $\begin{array}{l}0.161 \\
0.689\end{array}$ & $\begin{array}{l}0.718 \\
0.543\end{array}$ & $\begin{array}{l}100.054 \\
<\mathbf{0 . 0 0 1}\end{array}$ & $\begin{array}{l}0.482 \\
0.695\end{array}$ & $\begin{array}{l}3.235 \\
\mathbf{0 . 0 0 9}\end{array}$ & $\begin{array}{l}0.265 \\
0.997\end{array}$ & $\begin{array}{l}0.384 \\
0.981\end{array}$ \\
\hline Arrhoges occidentalis & $\begin{array}{l}\text { F-ratio } \\
\mathrm{p}\end{array}$ & $\begin{array}{c}67.30 \\
<\mathbf{0 . 0 0 1}\end{array}$ & $\begin{array}{l}0.478 \\
0.698\end{array}$ & $\begin{array}{c}24.95 \\
<\mathbf{0 . 0 0 1}\end{array}$ & $\begin{array}{l}0.188 \\
0.904\end{array}$ & $\begin{array}{c}11.98 \\
<\mathbf{0 . 0 0 1}\end{array}$ & $\begin{array}{l}0.776 \\
0.702\end{array}$ & $\begin{array}{l}0.577 \\
0.889\end{array}$ \\
\hline Ilyanassa spp. & $\begin{array}{l}\text { F-ratio } \\
\mathrm{p}\end{array}$ & $\begin{array}{c}105.3 \\
<\mathbf{0 . 0 0 1}\end{array}$ & $\begin{array}{l}4.293 \\
\mathbf{0 . 0 0 6}\end{array}$ & $\begin{array}{c}26.97 \\
<\mathbf{0 . 0 0 1}\end{array}$ & $\begin{array}{c}6.899 \\
<\mathbf{0 . 0 0 1}\end{array}$ & $\begin{array}{c}20.82 \\
<\mathbf{0 . 0 0 1}\end{array}$ & $\begin{array}{l}2.055 \\
0.016\end{array}$ & $\begin{array}{l}2.362 \\
\mathbf{0 . 0 0 5}\end{array}$ \\
\hline Bittiolum alternatum & $\begin{array}{l}\text { F-ratio } \\
\text { p- }\end{array}$ & $\begin{array}{l}7.445 \\
\mathbf{0 . 0 0 7}\end{array}$ & $\begin{array}{l}0.675 \\
0.569\end{array}$ & $\begin{array}{l}4.462 \\
\mathbf{0 . 0 0 1}\end{array}$ & $\begin{array}{l}0.470 \\
0.704\end{array}$ & $\begin{array}{l}2.455 \\
0.036\end{array}$ & $\begin{array}{l}0.900 \\
0.565\end{array}$ & $\begin{array}{l}0.873 \\
0.595\end{array}$ \\
\hline Nudibranchia & $\begin{array}{l}\text { F-ratio } \\
\mathrm{p}\end{array}$ & $\begin{array}{l}4.114 \\
0.044\end{array}$ & $\begin{array}{l}1.890 \\
0.134\end{array}$ & $\begin{array}{c}6.149 \\
<\mathbf{0 . 0 0 1}\end{array}$ & $\begin{array}{l}1.475 \\
0.224\end{array}$ & $\begin{array}{l}3.616 \\
\mathbf{0 . 0 0 4}\end{array}$ & $\begin{array}{l}1.885 \\
0.030\end{array}$ & $\begin{array}{l}1.405 \\
0.153\end{array}$ \\
\hline
\end{tabular}

whereas in mixed regions, they are evenly distributed throughout the water column (Tremblay \& Sinclair 1990, Raby et al. 1994, Gallager et al. 1996). It has been suggested that a minimum gradient in density is required for an observed response in larval vertical distribution (Tremblay \& Sinclair 1990). For example, a density $\left(\sigma_{t}\right)$ change $>0.007$ prevented larval movement on Georges Bank $(z<60 \mathrm{~m})$ (Tremblay \& Sinclair 1990). In the laboratory, the vertical distribution of $P$. magellanicus was restricted to either above or below the thermocline $\left(\Delta T=7^{\circ} \mathrm{C} \mathrm{m}^{-1}\right)$, and only larvae $>200 \mu \mathrm{m}$ could penetrate it (Gallager et al. 1996). In our study, the vertical structure of instabilities (i.e. mixing or turbulence) in the water column was intrinsically confounded by the temperature, density and salinity structure (Supplements 2 \& 3). Instabilities may also influence the vertical distribution of larvae, given that gastropod larvae may sink in response to turbulence (Fuchs et al. 2004, Young \& Chia 1987). The larval gastropods (Astyris lunata, Arrhoges occidentalis, Ilyanassa spp. and Bittiolum alternatum) that were abundant in the mixed layer are more likely to experience turbulence than those below the thermocline (Supplement 3).

Temperature and salinity affect the abundance, as well as development and survival rates, of many meroplanktonic species (Pechenik 1987); however, the effect of these physical factors on gastropod lar- vae is not well known. Growth rates increase with temperature, as observed for Ilyanassa obsolete and Crepidula plana (Lima \& Pechenik 1985, Scheltema 1967). In our study, Margarites spp., Littorinimorpha and Nudibranchia were found in greater abundance in the cooler waters below the thermocline, and may develop more slowly than taxa found predominantly in waters at or above the thermocline.

Temperature and salinity are scalar cues which can elicit larval behavioural responses (Young \& Chia 1987). For example, contact with a rapid change in density (temperature or salinity) causes some larvae to stop swimming and sink into denser water (e.g. crustaceans, echinoids, ascidians, bryozoans) or swim upwards (crabs, bivalves) (Young \& Chia 1987), allowing larvae to potentially select preferred or avoid lethal environments (e.g. cephalopods, Higgins et al. 2012). Behavioural responses to changes in temperature, salinity and density have yet to be studied in larval gastropods; however, they possess the sensory ability to detect changes in temperature and salinity (Kingsford et al. 2002). In the laboratory, when giant scallop larvae (Placopecten magellanius) contacted a temperature gradient, they appeared to move away from it (Gallager et al. 1996), possibly altering their swimming direction in a thermokinetic response to a rapid change in temperature (Kingsford et al. 2002, Daigle \& Metaxas 2011). This re- 
Table 6. Statistically significant results of post hoc multiple comparisons (Tukey's HSD test) for the 3-way ANOVA's (Table 5) that identified significant differences between depth $(z)$, and either tidal state (Ti) or lunar phase $(L)$. Numbers represent depths $(3,6,9,12,18$ and $24 \mathrm{~m})$. Only significant differences of larval abundance among depth are shown. Depths, separated by commas, are ordered sequentially ( 3 to $24 \mathrm{~m}$ ), not according to relative larval abundance at each depth. ns = no significant difference among depths

\begin{tabular}{|c|c|c|c|}
\hline Taxon & $\begin{array}{l}\text { Significant factor }(L, T i, z) \\
\text { interaction terms }\end{array}$ & $\begin{array}{l}\text { Factor levels } \\
\qquad(L, T i)\end{array}$ & $\begin{array}{l}\text { Multiple comparisons } \\
\text { of larval abundance among depths }(z)\end{array}$ \\
\hline Margarites spp. & $L \times T i \times z$ & $\begin{array}{l}\text { Full moon - ebb } \\
\text { Full moon - flood } \\
\text { Full moon - high } \\
\text { Full moon - low } \\
\text { Quarter moon - ebb } \\
\text { Quarter moon - flood } \\
\text { Quarter moon - high } \\
\text { Quarter moon - low }\end{array}$ & $\begin{array}{l}3,6,9,12<24 \\
3,6,9,12<18 \\
\mathrm{~ns} \\
3,6,9,12<18 \\
3,6,9,12,18<24 ; 3,6<18 \\
3,6<18 \\
3,6,9<18 \\
3,6,9,12<18,24\end{array}$ \\
\hline Diaphana minuta & $L \times T i \times z$ & $\begin{array}{l}\text { Full moon - ebb } \\
\text { Full moon - flood } \\
\text { Full moon - high } \\
\text { Full moon - low } \\
\text { Quarter moon - ebb } \\
\text { Quarter moon - flood } \\
\text { Quarter moon - high } \\
\text { Quarter moon - low }\end{array}$ & $\begin{array}{l}\mathrm{ns} \\
\mathrm{ns} \\
\mathrm{ns} \\
\mathrm{ns} \\
3,6,9,18,24<12 ; 24<9 \\
3,6,9,18,24<12 ; 3,18,24<9 \\
24<12 \\
3,24<12\end{array}$ \\
\hline Ilyanassa spp. & $L \times T i \times z$ & $\begin{array}{l}\text { Full moon - ebb } \\
\text { Full moon - flood } \\
\text { Full moon - high } \\
\text { Full moon - low } \\
\text { Quarter moon - ebb } \\
\text { Quarter moon - flood } \\
\text { Quarter moon - high } \\
\text { Quarter moon - low }\end{array}$ & $\begin{array}{l}\mathrm{ns} \\
\mathrm{ns} \\
\mathrm{ns} \\
\mathrm{ns} \\
9,12,18,24<3,6 ; 18,24<9 \\
6,9,12,18,24<3 ; 24<6 \\
9,12,18,24<6 ; 18,24<3 \\
12,18,24<6 ; 18,24<3\end{array}$ \\
\hline Crepidula spp. & $L \times z$ & $\begin{array}{l}\text { Full moon } \\
\text { Quarter moon }\end{array}$ & $\begin{array}{l}3,6,9,18,24<12 ; 3,24<9,18 \\
3,6,9,18,24<12\end{array}$ \\
\hline Astyris lunata & $L \times z$ & $\begin{array}{l}\text { Full moon } \\
\text { Quarter moon }\end{array}$ & $\begin{array}{l}3,6,18,24<12 ; 3,18,24<9 ; 24<6 \\
18,24<3,6,9,12\end{array}$ \\
\hline Littorinimorpha & $L \times \mathrm{z}$ & $\begin{array}{l}\text { Full moon } \\
\text { Quarter moon }\end{array}$ & $\begin{array}{l}3,6,9,12,24<18 ; 3,6,9<24 \\
3,6,9,12.24<18\end{array}$ \\
\hline Arrhoges occidentalis & $L \times z$ & $\begin{array}{l}\text { Full moon } \\
\text { Quarter moon }\end{array}$ & $\begin{array}{l}\text { ns } \\
3,6,9,18,24<12 ; 3,18,24<9 ; 18,24<6\end{array}$ \\
\hline Nudibranchia & $L \times z$ & $\begin{array}{l}\text { Full moon } \\
\text { Quarter moon }\end{array}$ & $\begin{array}{l}\text { ns } \\
3,6,9,12,18<24\end{array}$ \\
\hline Bittiolum alternatum & $z$ & & $3,9,12,18,24<6 ; 24<3,9,12$ \\
\hline
\end{tabular}

sponse may have evolved as a mechanism to avoid lethal or stressful temperatures (Higgins et al. 2012). Thus, the larval gastropods found above the thermocline in our study may have been responding to the thermocline by swimming upwards in order to remain in the mixed layer, where temperature changes are minimal $\left(\sim 1^{\circ} \mathrm{C}\right)$. The actual behavioural mechanisms regulating the response of these taxa to particular temperatures should be examined through controlled experiments.

In our study, the vertical distributions of 5 larval gastropod taxa were related to fluorescence. For Crepidula spp. and Littorinimorpha, which are plank- totrophic (Lebour 1937), the relationship with fluorescence was strong. The abundances of the other 3 gastropods (Astyris lunata, Diaphana minuta, Nudibranchia) were weakly related to fluorescence; these species are likely planktotrophic, as relatives in the same genus have planktotrophic veligers (Strathmann 1987a, Shanks 2001). The vertical distribution of planktotrophic larvae is often related to the presence of food patches (Raby et al. 1994, Metaxas \& Young 1998, Burdett-Coutts \& Metaxas 2004, Sameoto \& Metaxas 2008). Many larvae have chemosensory mechanisms to detect food (Kingsford et al. 2002), and laboratory studies have shown directed 


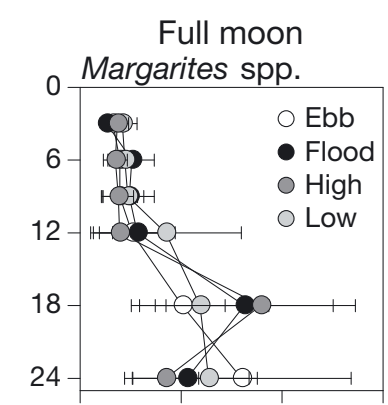

Quarter moon
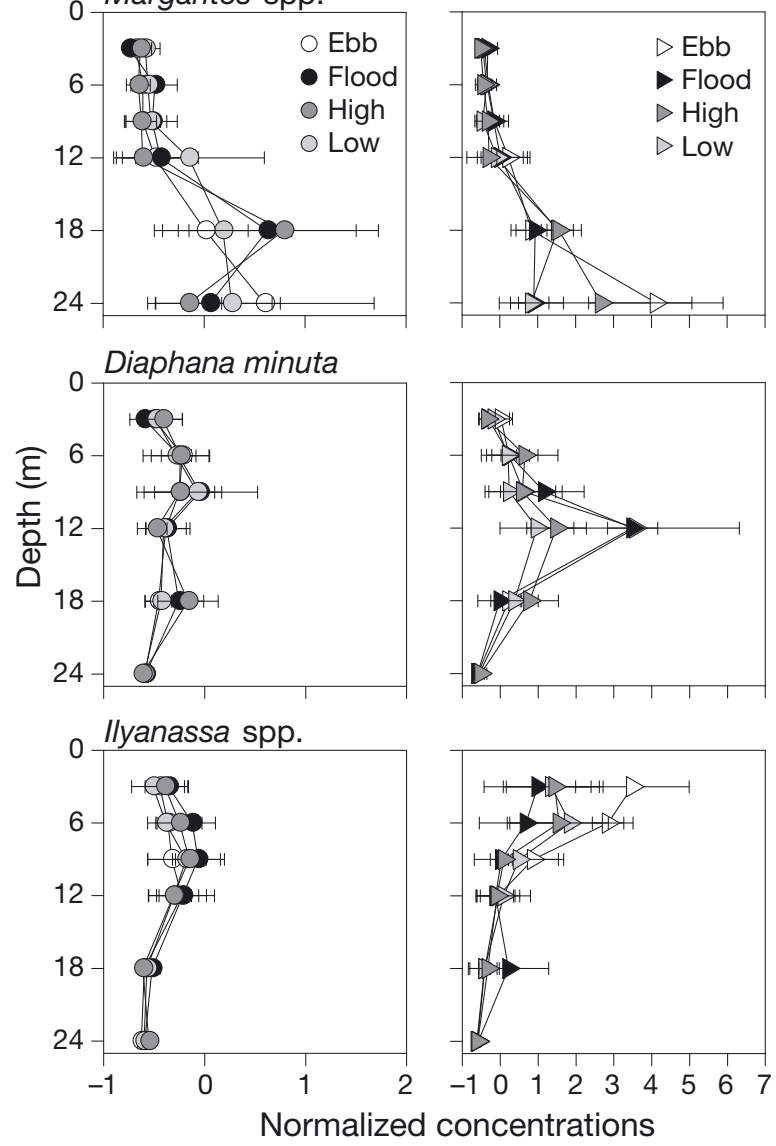

Fig. 6. Margarites spp., Diaphana minuta, Ilynassa spp. Vertical distribution of gastropod larvae, at each of 4 tidal states and 2 lunar phases (mean $\pm \mathrm{SD}, \mathrm{n}=2-6$ ) in St. George's Bay, Nova Scotia, Canada

movement towards food patches (Metaxas \& Young 1998, Burdett-Coutts \& Metaxas 2004, Sameoto \& Metaxas 2008). Once within the food patch, larvae modify their position and swimming behaviour to remain there (Metaxas \& Young 1998, Burdett-Coutts \& Metaxas 2004). As Littorinimorpha were most abundant around the fluorescence maximum, they may be more efficient at feeding at high food concentrations than other gastropod taxa (Strathmann 1987b); alternatively, food composition and size were optimum for feeding (Vargas et al. 2006, Blanchard et al. 2008). In order to remain within that layer, Littorinimorpha would likely have to modify their swimming behaviour to counteract any effect of vertical currents. Taxa that do not aggregate around the fluorescence maximum may be lecithotrophic, facultative or omnivorous (Strathmann 1987b, Vargas et al. 2006) feeders, or may be avoiding the chlorophyll maximum to avoid predators which tend to aggregate around prey fields (Vaughn \& Allen 2010).
Both increased chlorophyll and larval aggregations are often located at pycnoclines (Tremblay \& Sinclair 1990, Raby et al. 1994, Young 1995). In our study, however, the chlorophyll maximum was located below the thermocline. Many of the gastropod taxa were found either at or below the thermocline, potentially taking advantage of high food concentrations. However, the thermocline may also be acting as a barrier to the layer of maximum fluorescence for larvae found above the thermocline. In the laboratory, giant scallop (Placopecten magellanicus) and mussel (Mytilus edulis) larvae did not cross the thermocline and halocline, respectively, into a layer with higher food concentrations (Gallager et al. 1996, Pearce et al. 1996, Sameoto \& Metaxas 2008). However, more mussel larvae were observed at the halocline when algae were present than absent above the halocline (Sameoto \& Metaxas 2008). In the Baie des Chaleurs (Quebec, Canada), bivalve larvae were more abundant at the chlorophyll maximum at night in a stratified water column, than during the day or in a mixed water column (Raby et al. 1994). It is unknown whether gastropod larvae respond as bivalve larvae do to the presence of food layers or patches, but they may; as most are planktotrophic, and require sufficient and nutritionally adequate food to develop and survive (Pechenik 1987, Strathmann 1987b).

The vertical position of larvae can affect their direction and distance of dispersal, since current velocity generally varies with depth. In St. George's Bay, currents measured over a $43 \mathrm{~d}$ period were depth-dependent and fastest at the surface. Thus, larvae above the thermocline may have been transported farther than larvae near the seafloor, which in turn may be more likely to be retained near their source. The taxa that were more abundant below the thermocline (Margarites spp., Littorinimorpha, Nudibranchia) experienced currents moving away from shore (east). Many of these taxa settle in rocky- or soft-bottom habitat, in the infralittorial to bathyal zones (Brunel et al. 1998). In contrast, larvae (Astyris lunata, Bittiolum alternatum, Ilyanassa sp.) above the thermocline were being transported shoreward (southwest), where many would settle in the intertidal or shallow subtidal (hard and soft substrate, algae or eelgrass beds) (Brunel et al. 1998).

\section{Periodicity in larval vertical distribution}

Factors that can contribute to temporal variation in larval vertical distributions include advection, insta- 
bilities, vertical mixing, changes in density structure and larval behaviour. In our study, the vertical distributions of 5 larval gastropod taxa varied dielly and/ or tidally during 1 or both lunar phases, while the others only varied with lunar phase. We suggest that different mechanisms regulated each of these changes in larval vertical distribution.

If advection is responsible for changes in vertical distribution, larval abundance should correlate with current velocities, which was not the case for any taxonomic group. Additionally, if larval patches move through the sampling location, total larval abundance should vary over time. However, both the total (obtained from vertical net hauls across the entire water column, M. Lloyd unpubl. data) and the depthaveraged larval abundance at our sampling station remained relatively similar over a sampling period with only a few specific exceptions (see below), suggesting little horizontal advection. A lack of change in larval abundance over the entire water column suggests that loss in 1 layer is equal to gain in another, such as observed for some taxa between night and day. However, observed differences in larval vertical distribution among tidal states (ebb, flood, high and low tide) and between lunar phases (full and quarter moon) most likely resulted from changes in total larval abundance. These differences probably resulted from advection, particularly for differences among tidal states. Overall, the spatial variability in larval abundance $(U \mathrm{~d} L / \mathrm{d} x$, where $U$ is the horizontal velocity, $L$ is larval abundance and $x$ is distance) (R. Daigle unpubl. data) was 1.3 to 1000 times smaller than the observed temporal variability ( $\mathrm{d} L / \mathrm{d} t$, where $t$ is time) in our study, suggesting that horizontal gradients in advection did not play a significant role over hourly time scales.

As for horizontal advection, larval abundance was not related to instabilities and vertical velocities, and larvae within the mixed layer were equally likely to be found in stable and unstable water. Additionally, patterns in instabilities and vertical velocities did not show any periodicity that coincided with diel period or tidal state. Below the thermocline, the water column remained stable over time, suggesting that changes in larval vertical distribution (which most often were $>3 \mathrm{~m}$ ) were not the result of vertical mixing. Even though the direction of vertical velocities varied during the sampling period, larvae were likely able to actively regulate their vertical position within the water column, since their swimming speeds (e.g. Littorina littorea: $0.13 \mathrm{~cm} \mathrm{~s}^{-1}$, Chia et al. 1984) are greater than observed vertical velocities $\left(\right.$ mean $\left.\pm \mathrm{SD}=0.09 \pm 0.16 \mathrm{~cm} \mathrm{~s}^{-1}\right)$.
Changes in larval vertical distribution can be attributed to changes in the depth of the thermocline, halocline or pycnocline if larval abundance (mean depth distribution) correlates with the thermocline depth. This was not the case over the sampling period (M. Lloyd unpubl. data) although it appeared that the thermocline may have constrained larval vertical distribution to either above or below these features, possibly due to a change in buoyancy or a behavioural response.

We suggest that the observed diel changes in larval vertical distribution were mainly related to larval behaviour. Only 1 gastropod taxon (Margarites spp.) exhibited diel migration, migrating from the seafloor to the fluorescence maximum layer and shallower (>6 m) at night, presumably in response to changes in light when predation risk is low. The diel vertical migration by Crepidula fornicata in a sluice dock of Ostend $(1.5 \mathrm{~m})$ was attributed to negative phototaxis, since chlorophyll concentrations were minimal at the surface at night (Daro 1974). Similarly, gastropod larvae in Sevastopol Bay (Black Sea) swam upwards towards the surface in response to a reduction in light during a solar eclipse (Petipa 1955 as cited in Mileikovsky 1973). In contrast, diel vertical migration of gastropod larvae in an offshore region was attributed to predator avoidance (Garland et al. 2002). Both scyphozoans and fishes feed on larvae in St. George's Bay (Short et al. 2012). Thus, gastropod larvae may undertake diel migration to reduce predation risk from visual predators; it is unknown whether light and/or predation are the drivers of the patterns observed. Margarites spp. also potentially altered the magnitude of shoreward transport by vertically migrating from below the thermocline into the mixed layer.

Larvae of 3 gastropod taxa found at or above the thermocline exhibited reverse-diel migration. Astyris lunata, Ilyanassa spp. and Bittiolum alternatum may undertake reverse-diel migration to avoid dielmigrating predators, as do some copepods (Ohman et al. 1983). On the central coast of Chile, high concentrations of competent larvae of abalone Concholepas concholepas were found at the surface during the day, but not at night (Poulin et al. 2002). This reversediel migration was suggested as a mechanism to prevent offshore transport (Poulin et al. 2002). However, in our study, the taxa that undertook reverse-diel migration remained within the same (mixed) layer. Astyris lunata, Ilyanassa spp. and B. alternatum may only vertically migrate during the quarter moon, as a mechanism to increase shoreward transport, thus avoiding strong eastward currents, given that these 
species are commonly found in intertidal flats and eelgrass beds as adults (Brunel et al. 1998, Appeltans et al. 2011). The observed reverse-migration of these taxa may be the result of a behavioural response to increased occurrence of instabilities at 3-6 $\mathrm{m}$ at night during the quarter moon, rather than being related to the diel cycle. For example, larvae of Nassarius obsoletus sank when exposed to strong turbulence (Fuchs et al. 2004; Fuchs et al. 2010). Controlled experiments in the laboratory can unconfound potential cues (light, currents, predation, turbulence etc.), and determine behaviours associated with the vertical patterns observed in the field.

\section{CONCLUSION}

Although patterns in larval vertical distribution vary among gastropod taxa, they are most strongly related to temperature, fluorescence, and diel period. Our knowledge of the ecology of larval gastropods is limited, and is primarily focused on commercially important (e.g. Concholepas concholepas, Strombus gigas) and invasive (e.g. Crepidula fornicata) species. Here, we document the relationship between larval abundance of 9 gastropod taxa and physical and biological factors in the water column, and changes in their vertical distribution with respect to phases of the tidal, diel and lunar cycle. However, variation in the vertical distribution may result from larvae responding to more than 1 cue. The specific responses to different cues (temperature, chlorophyll, light, currents, stratification etc.) should be explored in laboratory studies. By associating changes in larval vertical distribution in the field with measured behavioural responses in the laboratory, we can begin to quantify the role of larval behaviour in the natural setting.

Acknowledgements. We thank R. Daigle, J. Short, S. Henderson, D. Ross, R. Stanley, J. Foley and J. Hrycik for assistance in the field; M. Merrimen, J. Lindley, W. Judge, D. Schillinger, C. Taggart and J. Grant for providing and assisting with equipment; A. Roy and R. Horricks for assistance in the laboratory; T. Ross, K. Colbo, and M. Lesperance for assistance with data processing. This study was part of the Canadian Healthy Oceans Network (CHONe). The research was funded by grants from the National Sciences and Engineering Research Council (NSERC) Strategic Network CHONe to A.M. and B. deY., and by a NSERC Discovery Grant to A.M.. M.J.L. was supported by fellowships from NSERC, CHONe, and the Faculty of Graduate Studies, Dalhousie University. Biogeographical data contained in this study will be submitted to the Oceanographic Biogeographic Information System (OBIS) and may be accessed on-line at www.iobis.org.

\section{LITERATURE CITED}

Appeltans W, Bouchet P, Boxshall GA, Fauchald K and others (eds) (2011). World register of marine species. Available at www.marinespecies.org

Barile P, Stoner A, Young C (1994) Phototaxis and vertical migration of the queen conch (Strombus gigas Linne) veliger larvae. J Exp Mar Biol Ecol 183:147-162

Blanchard M, Pechenik JA, Giudicelli E, Connan JP, Robert $\mathrm{R}$ (2008) Competition for food in the larvae of two marine molluscs, Crepidula fornica and Crassostrea gigas. Aquat Living Resour 21:197-205

Brunel P, Bossé L, Lamarche G (1998) Catalogue of the marine invertebrates of the estuary and Gulf of Saint Lawrence. Canadian Special Publication of Fisheries and Aquatic Sciences 126. NRC Research Press, Ottawa

$>$ Burdett-Coutts V, Metaxas A (2004) The effect of the quality of food patches on larval vertical distribution of the sea urchins Lytechinus variegatus (Lamarck) and Strongylocentrotus droebachiensis (Mueller). J Exp Mar Biol Ecol 308:221-236

Chia FS, Buckland-Nicks J, Young CM (1984) Locomotion of marine invertebrate larvae: a review. Can J Zool 62: 1205-1222

Collin R (2001) The effects of mode of development on phylogeography and population structure of North Atlantic Crepidula (Gastropoda: Calyptraeidae). Mol Ecol 10: 2249-2262

Daigle RM, Metaxas A (2011) Vertical distribution of marine invertebrate larvae in response to thermal stratification in the laboratory. J Exp Mar Biol Ecol 409:89-98

$>$ Daro MH (1974) Study of nycthemeral migrations of zooplankton in a shallow marine biotope. Hydrobiologia 44: 149-160

$>$ DiBacco C, Sutton D, McConnico L (2001) Vertical migration behavior and horizontal distribution of brachyuran larvae in a low-inflow estuary: implications for bay-ocean exchange. Mar Ecol Prog Ser 217:191-206

Forward RB (1988) Diel vertical migration-zooplankton photobiology and behavior. Oceanogr Mar Biol Annu Rev 26:361-393

Fuchs HL, Mullineaux LS, Solow AR (2004) Sinking behavior of gastropod larvae (Ilyanassa obsoleta) in turbulence. Limnol Oceanogr 49:1937-1948

Fuchs HL, Solow AR, Mullineaux LS (2010) Larval responses to turbulence and temperature in a tidal inlet: habitat selection by dispersing gastropods? J Mar Res 68:153-188

Gallager S, Manuel J, Manning D, O'Dor R (1996) Ontogenetic changes in the vertical distribution of giant scallop larvae, Placopecten magellanicus, in 9-m deep mesocosms as a function of light, food, and temperature stratification. Mar Biol 124:679-692

Garland ED, Zimmer CA, Lentz SJ (2002) Larval distributions in inner-shelf waters: the roles of wind-driven cross-shelf currents and diel vertical migrations. Limnol Oceanogr 47:803-817

> Higgins FA, Bates AE, Lamare MD (2012) Heat tolerance, behavioural temperature selection and temperaturedependent respiration in larval Octopus huttoni. J Therm Biol 37:83-88

Kingsford MJ, Leis JM, Shanks AL, Lindeman KC, Morgan SG, Pineda J (2002) Sensory environments, larval abilities and local self-recruitment. Bull Mar Sci 70:309-340 > Lebour MV (1937) The eggs and larvae of British proso- 
branchs with special reference to those living in the plankton. J Mar Biol Assoc UK 22:105-166

Lesperance M, deYoung B, Foley J (2011) Analysis of physical oceanographic data from St. George's Bay, NS JulyAugust 2009. Physics and Physical Oceanography Data Report 2011-1. Memorial University of Newfoundland, St. John's. Available at www.physics.mun.ca/ bdeyoung/ 2009report_8feb2011.pdf

Lima GM, Pechenik JA (1985) The influence of temperature on growth-rate and length of larval life of the gastropod, Crepidula plana Say. J Exp Mar Biol Ecol 90:55-71

Manuel JL, O'Dor RK (1997) Vertical migration for horizontal transport while avoiding predators: I. A tidal/diel model. J Plankton Res 19:1929-1947

> Manuel JL, Pearce CM, O'Dor RK (1997) Vertical migration for horizontal transport while avoiding predators: II. Evidence for the tidal/diel model from two populations of scallop (Placopecten magellanicus) veligers. J Plankton Res 19:1949-1973

Metaxas A (2001) Behaviour in flow: perspectives on the distribution and dispersion of meroplanktonic larvae in the water column. Can J Fish Aquat Sci 58:86-98

> Metaxas A, Young CM (1998) Responses of echinoid larvae to food patches of different algal densities. Mar Biol 130: 433-445

Ohman MD, Frost BW, Cohen EB (1983) Reverse diel vertical migration - an escape from invertebrate predators. Science 220:1404-1407

Pearce CM, Gallager SM, Manuel JL, Manning DA, O'Dor RK, Bourget E (1996) Settlement of larvae of the giant scallop, Placopecten magellanicus, in 9-m deep mesocosms as a function of temperature stratification, depth, food, and substratum. Mar Biol 124:693-706

Pechenik JA (1987) Environmental influences on larval survival and development. In: Giese AC, Pearse JS, Pearse VB (eds) Reproduction of marine invertebrates, IX, General aspects: diversity. The Boxwood Press, Pacific Grove, CA, p 551-608

Pennington JT, Emlet RB (1986) Ontogenetic and diel vertical migration of a planktonic echinoid larva, Dendraster excentricus (Eschscholtz): occurrence, causes, and probable consequences. J Exp Mar Biol Ecol 104:69-95

Petipa TS (1955) Observations on zooplankton behavior during the solar eclipse (in Russian). Dokl Akad Nauk SSSR 104:323-325, as cited in Mileikovsky S (1973) Speed of active movement of pelagic larvae of marine bottom invertebrates and their ability to regulate their vertical position. Mar Biol 23:11-17

Petrie B, Drinkwater K (1977) Physical oceanographic measurements in St. George's Bay, Nova Scotia. Report Series BI-R-77-5 June 1977. Bedford Institute of Oceanography, Dartmouth

Petrie B, Drinkwater K (1978) Circulation in an open bay. J Fish Res Board Can 35:1116-1123

> Poulin E, Palma AT, Leiva G, Narvaez D, Pacheco R, Navarrete SA, Castilla JC (2002) Avoiding offshore transport of competent larvae during upwelling events: the case of the gastropod Concholepas concholepas in Central Chile. Limnol Oceanogr 47:1248-1255

Rabiner LR, Gold B (1975) Theory and application of digital signal processing. Prentice-Hall, Englewood Cliffs, NJ

Raby D, Lagadeuc Y, Dodson JJ, Mingelbier M (1994) Relationship between feeding and vertical distribution of bivalve larvae in stratified and mixed waters. Mar Ecol
Prog Ser 103:275-284

Roughgarden J, Pennington T, Alexander S (1994) Dynamics of the rocky intertidal zone with remarks on generalization in ecology. Philos T Roy Soc B 343:79-85

Sameoto JA, Metaxas A (2008) Interactive effects of haloclines and food patches on the vertical distribution of 3 species of temperate invertebrate larvae. J Exp Mar Biol Ecol 367:131-141

Scheltema RS (1962) Pelagic larvae of New England intertidal gastropods. I. Nassarius obsoletus Say and Nassarius vibex Say. T Am Microsc Soc 81:1-11

- Scheltema RS (1967) Relationship of temperature to larval development of Nassarius obsoletus (Gastropoda). Biol Bull 132:253-265

Scheltema RS, Scheltema AH (1965) Pelagic larvae of New England intertidal gastropods III. Nassarius trivittatus. Hydrobiologia 25:321-329

Shanks AL (ed) (2001) An identification guide to the larval marine invertebrates of the Pacific Northwest. Oregon State University Press, Corvallis, OR

Short J, Metaxas A, Daigle RM (2012) Predation of larval benthic invertebrates in St. Georges Bay, Nova Scotia. J Mar Biol Assoc UK, doi:10.1017/S0025315412000768

Strathmann MF (1987a) Reproduction and development of marine invertebrates of the Northern Pacific coast: data and methods for the study of eggs, embryos and larvae. University of Washington Press, Seattle, WA

Strathmann RR (1987b) Larval feeding. In: Giese AC, Pearse JS, Pearse VB (eds) Reproduction of marine invertebrates, IX, general aspects: seeking unity in diversity. The Boxwood Press, Pacific Grove, CA, p 465-550

Thiriot-Quiévreux C (1980) Identification of some planktonic prosobranch larvae present off Beaufort, North Carolina. Veliger 23:1-10

Thiriot-Quiévreux C (1983) Summer meroplanktonic prosobranch larvae occuring off Beaufort, North Carolina. Estuaries 6:387-398

Thiriot-Quiévreux C, Scheltema RS (1982) Pelagic larvae of New England intertidal gastropods V. Bittium alternatum, Triphora nigroeincta, Cerithiopsis emersoni, Lunatia heros and Crepidula plana. Malacologia 23:37-46

Thorson G (1946) Reproduction and larval development of Danish marine bottom invertebrates, with special reference to the planktonic larvae in the Sound (Oresund). Medd Komm Havundersog Kbh Ser Plankton 4: 1-523

> Tremblay MJ, Sinclair MM (1990) Sea scallop larvae Placopecten magellanicus on Georges Bank: vertical distribution in relation to water column stratification and food. Mar Ecol Prog Ser 61:1-15

- Vargas CA, Manriquez PH, Navarrete SA (2006) Feeding by larvae of intertidal invertebrates: assessing their position in pelagic food webs. Ecology 87:444-457

> Vaughn D, Allen J (2010) The peril of the plankton. Integr Comp Biol 50:552-570

Young CM (1995) Behavior and locomotion during the dispersal phase of larval life. In: McEdward L (ed) Ecology of marine invertebrate larvae. CRC Press, Boca Raton, Florida, p 249-278

Young CM, Chia FS (1987) Abundance and distribution of pelagic larvae as influenced by predation, behavior, and hydrographic factors. In: Giese AC, Pearse JS, Pearse VB (eds) Reproduction of marine invertebrates, IX, general aspects: seeking unity in diversity. The Boxwood Press, Pacific Grove, CA, p 385-464 